\title{
RECREATIONAL TRAILS AS CORRIDORS FOR ALIEN PLANTS IN THE ROCKY MOUNTAINS, USA
}

\author{
Floye H. Wells ${ }^{1}$, William K. Lauenroth ${ }^{2}$, and John B. Bradford ${ }^{3}$
}

\begin{abstract}
Alien plant species often use areas of heavy human activity for habitat and dispersal. Roads and utility corridors have been shown to harbor more alien species than the surrounding vegetation and are therefore believed to contribute to alien plant persistence and spread. Recreational trails represent another corridor that could harbor alien species and aid their spread. Effective management of invasive species requires understanding how alien plants are distributed at trailheads and trails and how their dispersal may be influenced by native vegetation. Our overall goal was to investigate the distribution of alien plants at trailheads and trails in the Rocky Mountains of Colorado. At trailheads, we found that although the number of alien species was less than the number of native species, alien plant cover $(\bar{x}=50 \%)$ did not differ from native plant cover, and we observed a large number of alien seedlings in the soil seed bank, suggesting that alien plants are a large component of trailhead communities and will continue to be so in the future. Along trails, we found higher alien species richness and cover on trail (as opposed to $4 \mathrm{~m}$ from the trail) in 3 out of 4 vegetation types, and we observed higher alien richness and cover in meadows than in other vegetation types. Plant communities at both trailheads and trails, as well as seed banks at trailheads, contain substantial diversity and abundance of alien plants. These results suggest that recreational trails in the Rocky Mountains of Colorado may function as corridors that facilitate the spread of alien species into wildlands. Our results suggest that control of alien plants should begin at trailheads where there are large numbers of aliens and that control efforts on trails should be prioritized by vegetation type.
\end{abstract}

RESUMEN.—Las especies de plantas exóticas generalmente utilizan áreas de gran actividad humana como su hábitat y para su dispersión. Las carreteras y los corredores de utilidad albergan más especies exóticas que la vegetación circundante y, por lo tanto, se cree que contribuyen a la persistencia y propagación de plantas exóticas. Los senderos recreativos representan otro corredor que podría albergar estas especies y contribuir a su propagación. El manejo efectivo de especies invasoras requiere comprender de qué manera se distribuyen las plantas exóticas en las entradas de los senderos y en los senderos en sí y cómo su propagación puede estar influenciada por la vegetación nativa. Nuestro objetivo general fue investigar la distribución de plantas exóticas en las entradas de senderos y en los senderos de las Montañas Rocosas en Colorado. En las entradas de los senderos, descubrimos que, a pesar de que la cantidad de especies exóticas fue menor que la cantidad de especies nativas, la cobertura de plantas exóticas (un promedio del 50\%) no fue diferente de la cobertura de plantas nativas, y observamos un gran número de plántulas exóticas en el banco de semillas del suelo, lo que sugiere que las plantas exóticas son un gran componente de las comunidades que habitan las entradas de los senderos y continuarán siéndolo en el futuro. A lo largo de los senderos, encontramos mayor riqueza y mayor cobertura de especies exóticas en los senderos (en lugar de a 4 metros de distancia desde el sendero) en tres de cuatro tipos de vegetación y observamos más riqueza y cobertura de plantas exóticas en praderas que en los otros tipos de vegetación. Las comunidades de plantas en las entradas de los senderos y en los senderos, así como los bancos de semillas en las entradas de los senderos, contienen una diversidad y abundancia sustancial de plantas exóticas. Estos resultados sugieren que los senderos recreativos en las Montañas Rocosas de Colorado pueden funcionar como corredores que facilitan la propagación de especies exóticas en tierras silvestres. Nuestros resultados sugieren que el control de plantas foráneas debería comenzar en las entradas de los senderos donde existen grandes cantidades de estas especies exóticas y que se deberían priorizar los esfuerzos de control en los senderos según el tipo de vegetación.

Many alien plants depend on humans to expand their range (Hodkinson and Thomspon 1997, Mack and Lonsdale 2001). Human activity can introduce new plants both intentionally and unintentionally and often creates habitats that favor alien plant establishment (Mack and Lonsdale 2001, Mack 2005). Managers of National Parks and Forests and other natural areas are becoming increasingly concerned about invasive alien plants (Marler 2000). Past research has shown a positive relationship between visitation rates and the presence of alien plants (Lonsdale 1999). As recreational use in natural areas increases, the number of alien plants and the area they occupy can also be expected to increase, especially in sites disturbed

${ }^{1}$ Former Graduate Student, Graduate Degree Program in Ecology, Colorado State University, Fort Collins, CO 80523

${ }^{2}$ Corresponding author. Department of Botany, University of Wyoming, Laramie, WY 82071. E-mail: wlauenro@uwyo.edu

${ }^{3}$ U.S. Geological Survey, Southwest Biological Science Center, Flagstaff, AZ 86011. 
by human activity because of the strong link between disturbance by humans and the establishment of new plants (Hobbs and Huenneke 1992, Burke and Grime 1996).

There is evidence that human-made corridors often harbor alien plants. Roadsides and utility corridors both have been shown to harbor more aliens than surrounding vegetation (Tyser and Worley 1992, Panetta and Hopkins 1993, Rubino et al. 2002, Pauchard and Alaback 2004). Since human-made corridors link the front country to the backcountry, trails are of particular concern to managers of natural areas because they may provide a route for alien plant dispersal into wildlands. Several studies have documented higher numbers of alien species and cover directly next to the trail compared to the surrounding vegetation (Benninger-Truax et al. 1992, Campbell and Gibson 2001, Dickens et al. 2005, Potito and Beatty 2005, Gower 2008).

To understand the threat posed to natural areas by trails, trailheads deserve special consideration. Trailheads tend to be heavily disturbed areas with regular vehicle traffic and may provide a site for alien plant establishment. If trailheads harbor alien species, it is then possible for those plants to disperse along the trail corridor either by slowly establishing along the trail edges or by attaching to trail users (Mount and Pickering 2009).

Understanding the role of trailheads in harboring alien plants requires characterizing both the existing vegetation and the soil seed bank. Species that produce persistent soil seed banks usually have small seeds without additional structures for dispersal, such as awns or hairs (Thompson and Grime 1979, Thompson 1987). It is common for alien species with seeds that have these characteristics to travel as a contaminant in soil on the vehicles (Hodkinson and Thomspon 1997) or footwear (Clifford 1956, Salisbury 1961) of humans. The presence of significant alien seed abundance in the trailhead seed bank implies the potential for those alien species to disperse along the trail.

The few studies that directly link trails with the presence of alien plants focus on the difference between trails and roads (Tyser and Worley 1992, Stroh and Struckhoff 2009) or differences in use levels and types of trails, particularly if trails are used by horses and pack stock or by hikers alone (Benninger-Truax et al. 1992, Gower 2008). Hikers and horses have different types of impacts on the vegetation and soils (Pickering et al. 2010, Quinn et al. 2010). Horses pose a special concern since horse feces contain viable alien seeds that can then be deposited into natural areas (Campbell and Gibson 2001, Wells and Lauenroth 2007, Quinn et al. 2008).

Vegetation type may influence plant community resistance to alien establishment (Lonsdale 1999). In fact, some studies have found a significant relationship between vegetation type and the number or cover of alien plants (Larson et al. 2001, Pysek et al. 2002, Vilà et al. 2007, Stroh and Struckhoff 2009). Unlike many regions, where a trail passes through one dominant vegetation type, in the Rocky Mountains, trails generally pass through several distinct vegetation types. We explicitly included vegetation type in our study to determine whether vegetation type could be used by land managers to prioritize areas that are more prone to alien invasion.

We examined both trailheads and trails in the Colorado Rocky Mountains to determine if human activities were influencing alien plant establishment and spread. For trailheads, we had 2 objectives: (1) to determine the similarity between seeds in the seed bank at trailheads and seeds at adjacent ( $200 \mathrm{~m}$ away) sites without trailheads and (2) to determine the similarity between the plant communities at trailheads and those at adjacent sites without trailheads. For trails, we had 3 objectives: (1) to determine if trailsides harbored more alien plants than the adjacent plant communities, (2) to find out if some vegetation types were more heavily invaded than others, and (3) to examine use patterns to see if there was a connection between the level of use or the type of use and the presence of alien plants.

\section{Methods}

\section{Site Description}

Trailheads.-We sampled a total of 9 trailheads in the Colorado Rocky Mountains: 3 mountain trailheads on the western slope (western side of the Continental Divide), 3 mountain trailheads on the eastern slope, and 3 foothill trailheads on the eastern slope (Table 1). The trailheads were located in aspen forests, open meadows, and evergreen forests. The trailheads in the western slope mountains were in the White River National Forest at 


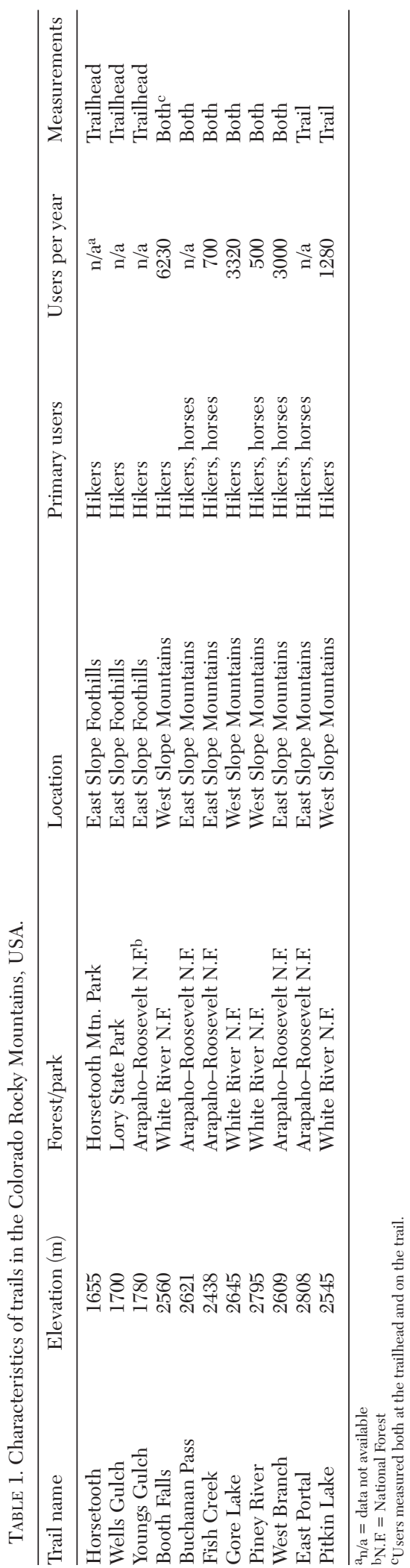

elevations between 2500 and $2800 \mathrm{~m}$. The trailheads in the eastern slope mountains were in the Arapaho-Roosevelt National Forest at elevations between 2400 and $2620 \mathrm{~m}$. The eastern slope foothill trailheads were in a state park, a county park, and the Arapaho-Roosevelt National Forest at elevations between 1600 and $1800 \mathrm{~m}$.

TraILS.-We sampled 4 trails in summer 2003 on the western slope of the Rocky Mountains in the White River National Forest and 4 trails in summer 2004 on the eastern slope of the Rocky Mountains in the Arapaho-Roosevelt National Forest (Table 1). Although it would have been preferable to sample all the trails in one season, this was not possible. However, since each plot was being compared only to other plots on that same trail, the difference in collection years should not greatly affect the core question, which is whether the trailside plot has more aliens than the adjacent plot.

\section{Data Collection}

Trailheads.-We collected seed bank samples in early June 2004. We chose this date because it was early enough that few new seeds had dispersed. Seeds in the seed bank had overwintered and therefore received a cold treatment if necessary for germination. At each trailhead, we established 2 sampling sites: a trailhead site and an adjacent site. The trailhead site was directly at the trailhead (where the trail departs from the road or parking lot), and the adjacent site was approximately $200 \mathrm{~m}$ away from the trailhead and consisted of the same vegetation type, slope, and aspect as the trailhead site. We placed the adjacent site at the same distance from the road as the trailhead site to ensure that we were sampling a trail effect and not a road effect.

Our seed bank methods are similar to those described by Coffin and Lauenroth (1989). We took 5 samples at each site. Each sample was randomly located by distance (0-10 paces) and cardinal direction either from the corner of the trailhead signpost closest to the trail or from a random center at the adjacent site. Each sample consisted of 2 pooled subsamples. Each subsample was a soil core $7.5 \mathrm{~cm}$ in diameter and $5 \mathrm{~cm}$ deep. When possible, we took one subsample in the vegetation and the other in bare soil. We allowed samples to air-dry for 
5-10 days and then passed them through a $0.5-\mathrm{cm}^{2}$ screen. The sieved soil was evenly distributed on sterile potting soil in standard trays in the greenhouse, watered daily, and fertilized with a commercial fertilizer (Scott's MiracleGroTM) every 2 weeks. Seedlings were identified and removed from the trays as they emerged to ensure that space and nutrients were available for new seedlings. If a seedling could not be identified, it was transferred to a large pot and identified at a later growth stage. We identified plants and assigned their origin as native or alien using Weber and Wittmann (2001a, 2001b). Seedling emergence was monitored for 4 months, at which point the trays were discarded. Following Coffin and Lauenroth (1989), we reported seedling abundance in units of the number of seedlings per $\mathrm{m}^{2}$ of ground area.

To measure plant cover, we used four $1-\mathrm{m}^{2}$ plots located at random cardinal directions and distances (0-10 paces) from the trailhead signpost closest to the trail for the trailhead sites and from a random center for the adjacent sites. Using cover classes (Daubenmire 1959), we recorded the species within the plot and estimated percent cover for each species. We averaged the values for the 4 plots to get a single description of the plant community at each site.

TraILS.-In the first $2000 \mathrm{~m}$ of each trail, we measured the distance occupied by 4 vegetation types (aspen forest, evergreen forest, meadow, riparian area) using a distance measuring wheel. We calculated the percentage of the trail that fell within each vegetation type and allocated 20 sampling points proportionately so that if $20 \%$ of the first $2000 \mathrm{~m}$ passed through meadow vegetation, $20 \%$ of the sampling points were located in meadows. The sampling points were randomly located within vegetation type. Two trails, Gore Lake and Lower Piney River, had only 19 points.

In order to determine which environmental variables were correlated with the presence of alien species, at each sampling point, we recorded a GPS coordinate, elevation, percent slope, aspect, and the width and depth of the trail. We established two $1 \times 3$-m quadrats, one directly adjacent to the trail, with its long axis parallel to the trail's edge (the "on" quadrat), and another $4 \mathrm{~m}$ from the trail's edge (the "off" quadrat). Within each quadrat, we recorded understory species presence, understory spe- cies cover according to established cover classes (Daubenmire 1959), and tree canopy cover measured with a densiometer. We identified plants and assigned their origin as native or alien, using definitions of Weber and Wittmann (2001a, 2001b).

We considered Poa pratensis L. to be a native. Poa pratensis L. is usually recorded as an alien grass, but we chose not to do so since it has a closely related native species, Poa agassizensis B. Boivin \& D. Löve, which is difficult to distinguish from the alien species. In order to ensure that we did not overreport the number of alien species, plants that we could identify to genus but not to species were included as natives.

We gathered trail-use data from the USDA Forest Service. The White River National Forest provided use estimates from trail registers, and the Arapaho-Roosevelt National Forest provided estimates based on volunteer observations. We analyzed total visitor estimates as a continuous variable and whether or not pack stock commonly used the trail as a categorical variable.

\section{Analysis}

Trailheads.-We used Jaccard's coefficient (Krebs 1989) to determine the similarity between the species in the seed bank at each paired trailhead and adjacent site, the similarity between the vegetation at the trailhead and adjacent site, and the similarity between the seed bank and the vegetation at each site. We used a weighted coefficient for cover and an unweighted coefficient for the vegetation and the seed bank. The weighted coefficient compares percent cover, while the unweighted coefficient compares only species presence. Jaccard's coefficient provides an index of similarity between 2 communities and is reported as percent similarity.

We used linear regression in SAS PROC GLM (SAS 2001) to model the number of native and alien species and the number of native and alien seedlings from the seed bank as a response to site (trailhead or adjacent). The variable assessing whether the trail was on the east slope or west slope of the Rocky Mountains was removed from the analysis because it was not significant. We used linear regression to model the number of alien and native species (species richness) and alien and native cover classes as a response to site. Cover class 


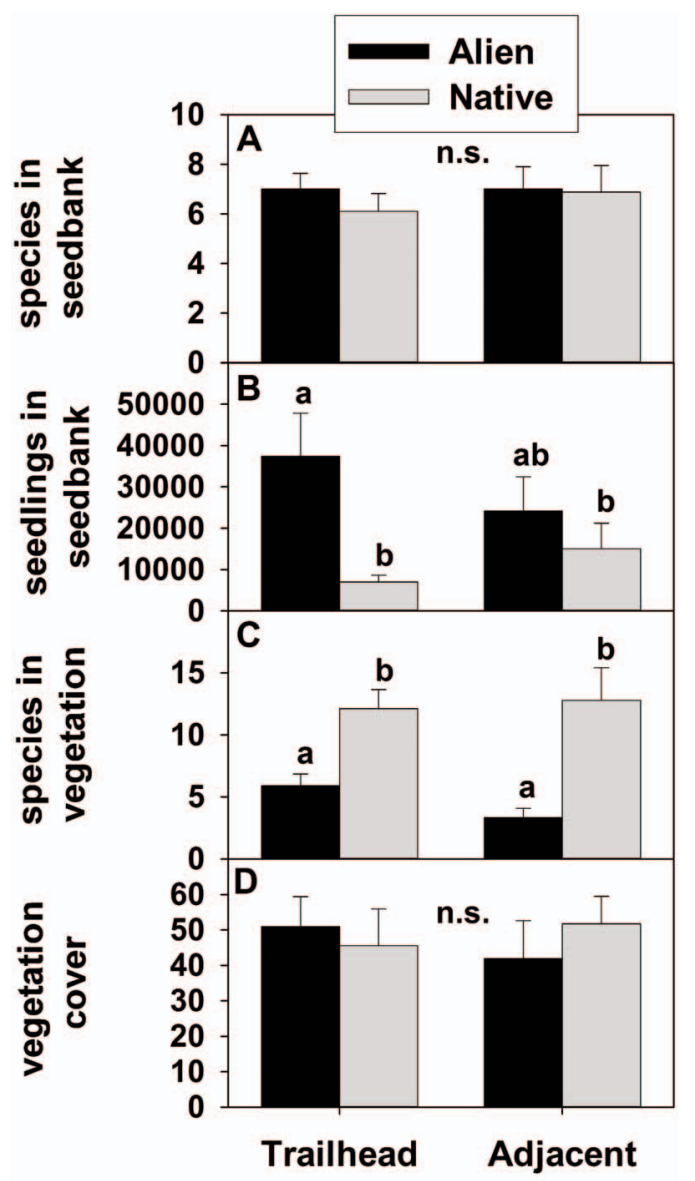

Fig. 1. The number of species per sample in the soil seed bank at the sites with trailheads and adjacent sites (A), the number of seedlings per $\mathrm{m}^{2}$ at trailhead and adjacent sites (B), species richness at trailhead and adjacent sites for aliens and natives (C), and percent cover for aliens and natives at trailhead and adjacent sites (D). Error bars represent standard errors, and lowercase letters indicate significant differences between alien and native plants. Overall differences between trailhead sites and adjacent sites was not significant for any comparison.

values were square-root transformed to meet the assumption of normality. Statistical significance is $\alpha=0.05$ unless otherwise stated.

Trails.-To determine the importance of vegetation type and proximity to the trail (on or off), we used a split-plot design with trail as block, vegetation type as whole-plot treatment, the 20 sampling locations as subsamples nested within trail and vegetation type, and the on and off quadrats as a split of the subsample. We used the SAS program PROC MIXED (SAS 2001). We used a square-root transfor- mation for percent cover calculations to normalize variance and increase the linearity of the response. We tested the importance of use by adding it to the PROC MIXED model.

In addition to use and vegetation type, we also included environmental variables and community similarity between the on and off quadrats in our analysis. We used linear regression to determine the importance of the environmental variables (percent slope, aspect, elevation, and tree canopy cover), and we compared the plant communities by calculating Jaccard's coefficient of similarity for each onoff pair (Krebs 1989).

\section{RESUlTS}

Trailheads

SOIL SEED BANK.-We encountered 29 alien species and 52 native species in our seed bank samples (see Appendix 1 for a complete list of species). The number of species in the seed bank at trailhead and adjacent sites was similar (Fig. 1A). There was a mean of 7 alien species (range 5-10) and 6 native species (2-8) in the seed bank at the trailhead sites and a mean of 7 aliens (4-12) and 7 natives (2-12) at the adjacent sites. The difference between sites was not significant.

The number of seedlings emerging from the soil seed bank (sampled to $5 \mathrm{~cm}$ depth) was significantly dominated by aliens at both trailhead and adjacent sites (Fig. 1B). There was a mean of 3746 alien seedlings (range 408-8470) and 702 native seedlings (159-1585) per $\mathrm{m}^{2}$ at the trailhead sites and a mean of 2415 alien seedlings (113-6907) and 1507 native seedlings (159-6183) per $\mathrm{m}^{2}$ at the adjacent sites. There was no significant difference between the number of alien seedlings at the trailhead sites and the adjacent sites, nor was there a significant difference between the numbers of natives. However, similarity between the species in the seed banks at the trailhead sites and the species in the seed banks at the adjacent sites was low (Table 2). The mean Jaccard's coefficient $(J)$ was only $28 \%$ and ranged from $19 \%$ to $42 \%$ (Table 2 ).

On a per species basis, aliens had a mean of 206 seedlings per species and natives had 74 seedlings per species. Native and alien seedling numbers had a similar frequency distribution, but aliens were more evenly distributed while natives had more species with low 
TABLE 2. Jaccard's coefficient of similarity between trailheads and adjacent sites (trailheads vs. adjacent) in the seed bank and the existing vegetation (seedbank vs. vegetation) and between the germinable seed bank and the existing vegetation at trailheads and adjacent sites. Jaccard's coefficient is reported as a percentage between 0 and 100 , with high values indicating high similarity.

\begin{tabular}{lcccc}
\hline \multirow{2}{*}{ Trailhead } & \multicolumn{2}{c}{ Trailheads vs. adjacent } & \multicolumn{2}{c}{ Seedbank vs. vegetation } \\
\cline { 2 - 4 } & Seed bank & Vegetation & Trailhead & Adjacent \\
\hline Booth Falls & 19 & 23 & 19 & 22 \\
Gore Creek & 18 & 14 & 19 & 12 \\
Piney River & 42 & 16 & 15 & 19 \\
Buchanan Pass & 27 & 13 & 14 & 8 \\
Fish Creek & 15 & 56 & 17 & 9 \\
West Branch & 25 & 7 & 17 & 26 \\
Horsetooth & 36 & 41 & 11 & 10 \\
Wells Gulch & 39 & 12 & 14.2 & 26 \\
Youngs Gulch & 31 & 27 & 23.2 & 13 \\
MEAN & 28.0 & & & 16.1 \\
\hline
\end{tabular}

numbers of seedlings (Fig. 2). Out of the seedlings that sprouted in the trays, there were 7 alien species with over 200 seedlings (in ascending order): Poa compressa L., Bromus inermis Leyss., Poa annua L., Verbascum thapsus L., Verbena bracteata Lagasca \& Rodriguez, Spergularia rubra (L.) Presl., and Bromus tectorum L. There were only 3 native species with over 200 seedlings: Silene antirrhina L., Sporobolus cryptandrus (Torrey) Gray, and Juncus bufonious L.

Trailhead vegetation.-Overall, the plant communities at trailhead and adjacent sites were dissimilar, with a mean $J$ value of $23 \%$, ranging from $7 \%$ to $56 \%$ (Table 2 ). We found 26 alien species and 111 native species (see Appendix A for a list of species). Two species that we could not identify were removed from the analysis. These species were rare, with fewer than 10 seedlings each. There were significantly fewer alien species than native species at both trailhead and adjacent sites (Fig. 1C). However, the difference between aliens at the trailhead sites and aliens at the adjacent sites was not significant, nor was the difference between natives at the trailhead sites and natives at the adjacent sites. There was a mean of 6 aliens (range 1-9) and 12 natives (6-22) at the trailhead sites and a mean of 3 aliens (1-8) and 13 (2-24) natives at the adjacent sites.

Even though the number of alien species was significantly less than the number of native species, cover values contributed by aliens did not differ from cover contributed by natives (Fig. 1D). At the trailhead sites, the mean alien cover was $51 \%$ (range $28 \%-94 \%$ ) and the mean native cover was $46 \%$ (16\%-119\%). At the adjacent sites, the mean alien cover was
$42 \%(1 \%-86 \%)$ and the mean native cover was $52 \%(8 \%-80 \%)$.

On a per species basis, aliens had a higher mean cover than natives. Aliens had a mean cover of $10 \%$ per species and natives had a mean cover of $4 \%$ per species. Overall, aliens were more evenly distributed between low numbers and high numbers per species, and natives were heavily weighted by a large number of species with low cover values (Fig. 3).

The species that were dominant in the seed bank were poorly represented in the vegetation plots. The mean $J$ value for the similarity between the seed bank and the vegetation was only $15 \%$ and ranged from $4 \%$ to $26 \%$. Some examples of this dissimilarity include the alien species Verbascum thapsus L. and the native species Spergularia rubra (L.) Presl. Verbascum thapsus L. was present in the seed bank at every site, but recorded only once in the vegetation survey, and Spergularia rubra (L.) Presl, which was the most abundant species in the seed bank at many of the trailhead sites, occurred at only 2 trailhead sites, where it had a cover of $<1 \%$. The native grass Bromus inermis Leyss. was the only species that was abundant in both the soil seed bank and the plant community of the vegetation plots.

\section{Trails}

VEGETATION TYPES.-We sampled a total of 158 plots: 35 in meadows, 57 in aspen forests, 57 in evergreen forests, and 9 in riparian areas. These plots were dispersed throughout the first $2000 \mathrm{~m}$ of the 8 trails (Fig. 4). Aspen forest vegetation type plots were equally distributed throughout the entire distance; meadow plots were generally concentrated at 


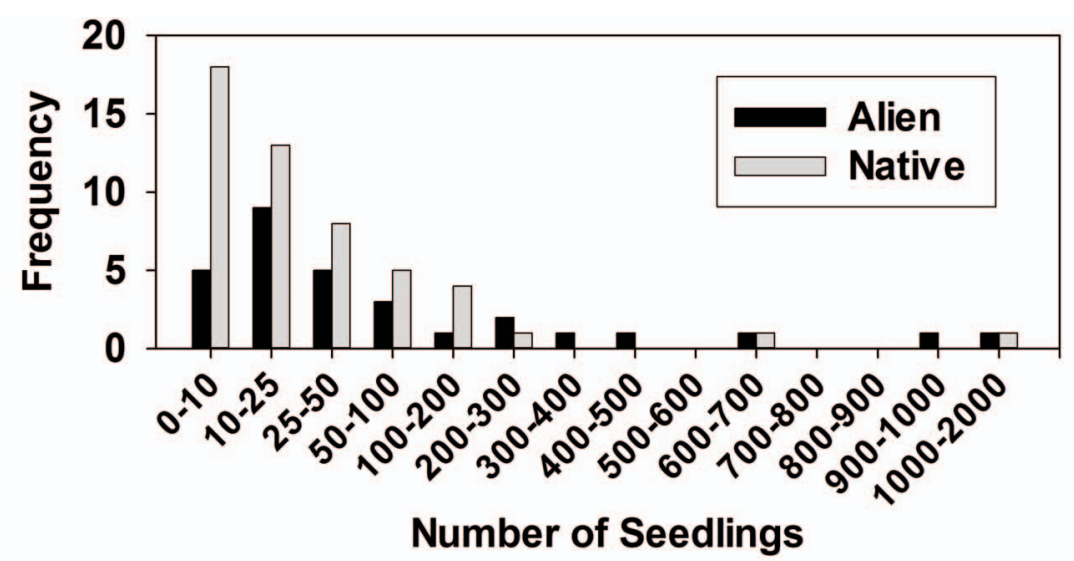

Fig. 2. Histogram of seedlings per $\mathrm{m}^{2}$ per species for aliens and natives in the seed bank.

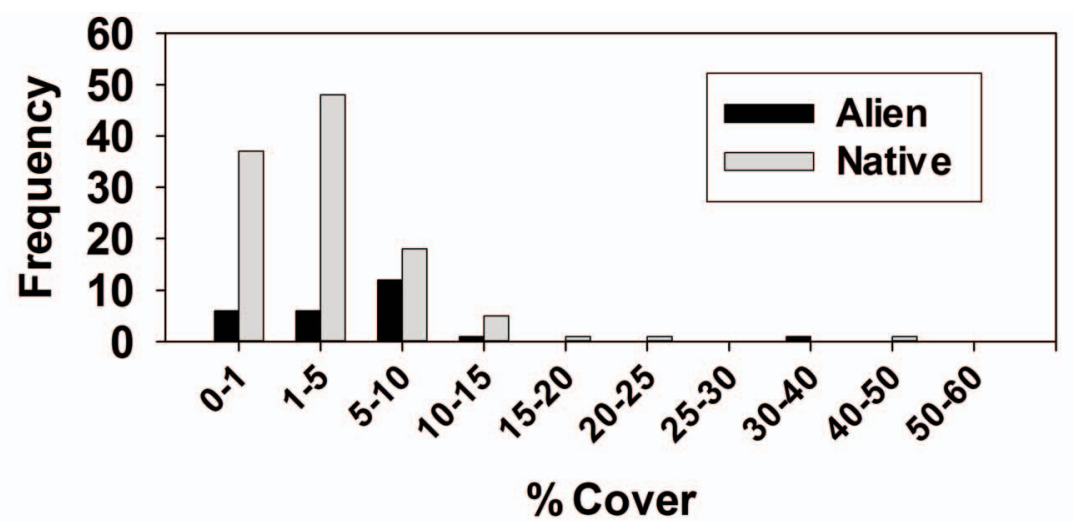

Fig. 3. Histogram of percent cover per species for alien and native plants at trailhead and adjacent sites. Aliens had a mean cover of $10 \%$ per species, and natives had a mean cover of $4 \%$ per species.

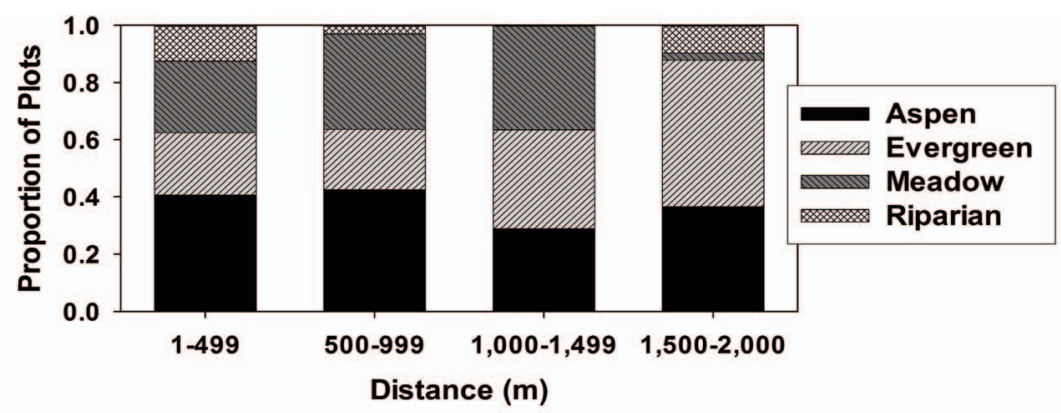

Fig. 4. The distribution of plots among vegetation types and distances (the first $2000 \mathrm{~m}$ of a trail).

intermediate distances; evergreen forest plots were generally farther from the trailhead; and riparian plots were mostly located in the first and last $500 \mathrm{~m}$ of our sampling distance.
We found a total of 210 native species (Appendix 2). Native species richness differed among the 4 vegetation types (Fig. 5A). The meadow and aspen forest vegetation types 


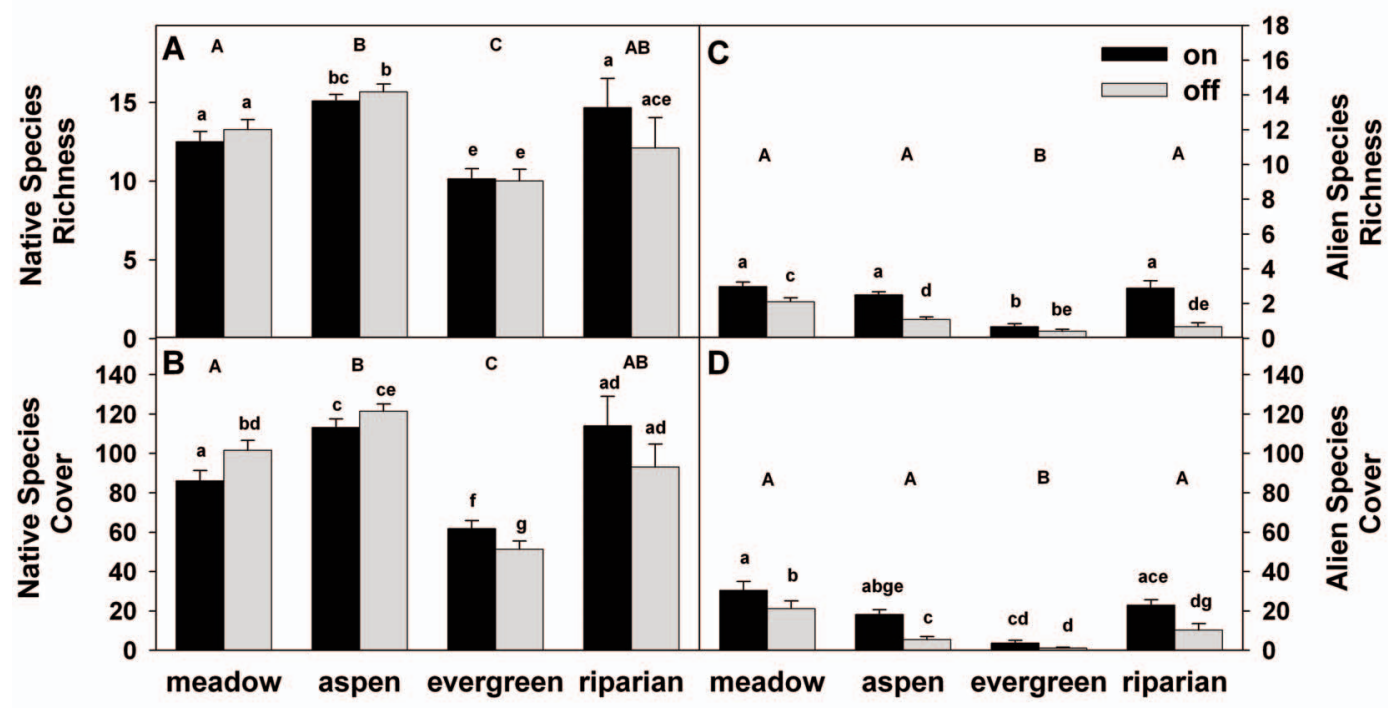

Fig. 5. Native species richness (A), native species cover (B), alien species richness (C), and alien species cover (D) for the on- and off-trail locations within each vegetation type. Bars represent standard error; different small letters indicate significant differences between on- and off-trail locations, and different uppercase letters indicate significant differences between vegetation types. Statistical significance for alien cover was determined using data that had been root transformed.

differed from each other, but neither was significantly different from the riparian areas, and all 3 had significantly more species than the evergreen forest. The number of native species on trail and off trail did not differ in any vegetation type.

Native percent cover followed a pattern similar to that of native species richness (Fig. $5 \mathrm{~B})$. The meadow and aspen forests differed from each other, but not from the riparian areas, and all 3 had significantly greater native cover than the evergreen forests. There was not a significant difference between native cover on trail and off trail in the aspen forests or the riparian areas, but there was a significant difference between the native cover on trail and off trail in meadows and evergreen forests, with meadows having greater native cover off trail and evergreen forests having greater native cover on trail.

The overall percent similarity between the vegetation along the trails and the vegetation in the adjacent lands was low. Jaccard's coefficient of similarity $(J)$ for the comparison between the on trail and off trail in meadows was $23 \%$ (range 3\%-36\%). In aspen forest vegetation types, $J$ was $21 \%(1 \%-34 \%)$; in evergreen forests, $16 \%$ (0\%-44\%); and, in riparian areas, $10 \%$
$(0 \%-22 \%)$. In addition, trail width, but not depth, varied among vegetation types. Trails were significantly wider in evergreen forests $(145 \mathrm{~cm})$ and riparian areas $(129 \mathrm{~cm})$ than they were in meadows $(96 \mathrm{~cm})$ and aspen forests $(91 \mathrm{~cm})$.

Tree canopy cover showed high cover values in evergreen forests, low cover values in meadows, and intermediate values in both aspen forests and riparian areas (Fig. 6A). We did not find a difference between tree canopy cover on trail and off trail. Percent cover of bare ground followed the same pattern as tree canopy cover, with high values in the evergreen forests and low to intermediate values in the meadow, aspen forest, and riparian areas (Fig. 6B). Riparian areas were the only vegetation type with significant difference between the bare ground on trail and off trail, exhibiting more bare ground off trail.

ALIEN SPECIES.-We found a total of 27 alien species (Appendix 2), but no more than 7 species in any quadrat. We observed significantly more alien species and alien percent cover on trail than off trail in all vegetation types except evergreen forests (Fig. 5C). The meadows had a mean of 3 species on trail (range 0-6) and 2 off trail (0-6); the aspen 


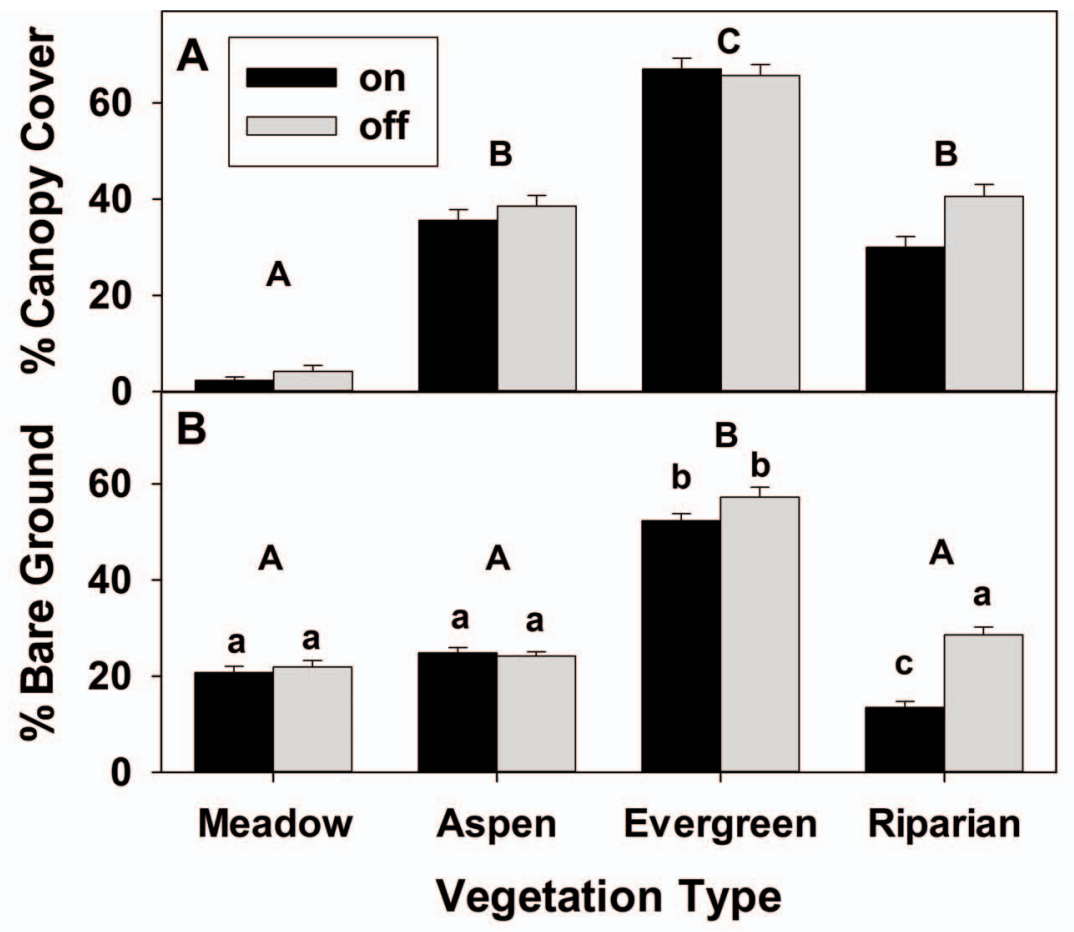

Fig. 6. Tree canopy cover (A) and percent bare ground (B) in the on- and off-trail locations within each vegetation type. The difference between the on- and off-trail locations in A is not significant. Bars represent standard error of the mean; different lowercase letters indicate significant differences between the on- and off-trail locations, and different uppercase letters indicate significant differences between vegetation types.

forests had a mean of 3 species on trail $(0-5)$ and 1 off trail $(0-4)$; the evergreen forests had a mean of 1 species on trail $(0-7)$ and $<1$ off trail (0-4); and the riparian areas had a mean of 3 species on trail (2-6) and 1 off trail (0-2).

ENVIRONMENTAL VARIABLES.-We excluded aspect from our analysis because most of the trails were on south-facing slopes, and we used distance from the trailhead rather than elevation since the 2 were highly correlated. All the trails gained elevation from the trailhead. The combination of percent slope, distance, and tree canopy cover accounted for $30 \%$ of the variance in percent cover for aliens. Percent slope had a negligible effect, while distance and canopy cover were both significant for explaining the presence of alien species. All 3 variables interacted significantly with vegetation type.

USE.-We obtained trail-use data for 6 of the 8 trails (Table 1 ). The number of visitors per year ranged from $<1000$ visitors per year to $>6000$ visitors per year. Five of the 8 trails were used by horses, but estimates of the number of visitors on horseback and those hiking were not available. Neither the number of visitors, analyzed as a continuous variable, nor whether or not the trail was used by horses, analyzed as a categorical value, was significant for explaining either the number of alien plants or the percent cover of alien plants along the trail.

\section{Discussion}

Trailheads represent the point where the front country meets the backcountry and these results underscore the role that trailheads and trails may be playing in alien species dispersal into the backcountry. At the trailheads we examined, both the seed banks and the vegetation contained considerable numbers of alien species, and trailhead seed banks and vegetation differed from adjacent areas without trailheads. Although the trailheads and adjacent areas that we examined contained significantly fewer alien species than native species, the percent cover of aliens and natives did not 
differ. Aliens had a higher percent mean cover per species, in addition to a higher number of seedlings per species. Species-specific studies have shown that alien species can have high cover values, as well as many seedlings in the seed bank within a plant community (Vitousek 1990, D’Antonio and Vitousek 1992, Humphrey and Schupp 2001, Alexander and D'Antonio 2003).

Although the number of aliens did not differ between trailheads and adjacent sites, species composition between these locations were different. This difference cannot be entirely explained by the presence of alien species and may be partially a result of more frequent disturbances at trailhead sites (e.g., trampling). Our observation of high exotic species cover in both sites may be a consequence of close proximity to roads, which have been shown to harbor alien species (Tyser and Worley 1992, Pauchard and Alaback 2004).

Plant species in the seed bank and the plants growing at our sites were not similar, a relatively common finding in seed bank studies (Thompson and Grime 1979, Coffin and Lauenroth 1989, Leck et al. 1989, Jalili et al. 2003). In fact, it is common to find some species exclusively in the seed bank and some species exclusively in the vegetation and vice versa (Maccherini and De Dominicis 2003). In a study comparing the forest edge to the interior vegetation, Honu and Gibson (2008) found that over $50 \%$ of the native plants in their study were unrepresented in the seed bank and that over $50 \%$ of the alien species were found in the seed bank but not in the extant vegetation. Many alien species have seeds that remain viable in the soil seed bank for a long time (Burnside et al. 1996, Alexander and D'Antonio 2003). Fluctuations in resource levels are tied to the invisibility of communities (Davis et al. 2000). If resources become available and if there are alien propagules available to take advantage of those resources, then invasions are more likely to occur. In the case of the soil seed bank, there are abundant propagules that are poised to take advantage of advantageous resource fluctuations at the trailhead, as well as at locations farther along the trail if those propagules are transported as a contaminant on shoes, etc. (Clifford 1956, Salisbury 1961, Mount and Pickering 2009).

The patterns of alien species along the trails we examined, when contrasted with the sur- rounding vegetation, imply that trails may be serving as invasion corridors. Vegetation next to the trail contained more aliens than plots located only $4 \mathrm{~m}$ from the trail's edge in 3 out of the 4 vegetation types, implying that the replacement of native species by aliens may contribute to the low compositional similarity between the trailside vegetation and the surrounding vegetation. Similarly, the percent cover contributed by aliens was significantly higher next to the trail in all community types except evergreen forests. The presence of alien species along the edge of the trail is consistent with other work (Benninger-Truax et al. 1992, Tyser and Worley 1992, Dickens et al. 2005, Potito and Beatty 2005, Gower 2008) and demonstrates that propagules are arriving at those sites and that conditions for growth are suitable. In addition, the greater abundance of alien species along the trail compared to surrounding areas implies limited successful migration away from trails, perhaps because the alien species are less able to compete with the native vegetation farther away from the trail where natives may have a competitive advantage in the absence of trampling stress.

Vegetation type appears to influence the magnitude and pattern of alien plant species invasion along trails. Specifically, meadows, aspen forests, and riparian zones are likely to harbor alien plants, and evergreen forests are likely to contain a negligible number of alien plants. In addition to harboring alien plants along the edge of the trail, meadows had significantly higher alien species richness and cover at the off-trail location $(4 \mathrm{~m}$ from the trail's edge) than the other 3 vegetation types.

We expected to confirm the findings of Lonsdale (1999) that a positive correlation exists between visitors and aliens, but we did not find a significant relationship between the number of visitors and the presence of alien species. Although pack stock cause additional disturbance and have the potential to introduce seeds as both contaminants in their dung (Campbell and Gibson 2001, Wells and Lauenroth 2007) and external contaminants, we did not find a relationship between the presence of aliens and whether or not the trail was used by pack stock.

We found that trailheads and trails both alter native plant communities. Trailheads represent the first point of contact between visitors and wildlands. Though our results suggest 
trailheads are not significantly more invaded than adjacent sites without trailheads, trailheads are heavily invaded, and management should focus on trailheads as locations from which introductions of new plant species can spread along trail corridors to the backcountry. The greater number and cover of alien plants along trails than in the adjacent vegetation suggest that trails are indeed corridors along which alien plants move. Furthermore, the apparent success of alien plants that disperse along trail corridors depends upon vegetation type. Control of alien plants should consider the potential impact of trailheads, where there are large numbers of aliens, and efforts to minimize or mitigate invasion along trails may be most effective if focused on the most invaded vegetation types.

\section{ACKNOWLEDGMENTS}

We thank Chris Warren for help with the trailhead data collection. This work was supported by the Colorado State University Agricultural Experiment Station through grant number 1-57661 and by the National Science Foundation through grant number 0217631. Any use of trade, product, or firm names is for descriptive purposes only and does not imply endorsement by the U.S. Government.

\section{Literature Cited}

Alexander, J.M., And C.M. D’Antonio. 2003. Seed bank dynamics of French broom in coastal California grasslands: effects of stand age and prescribed burning on control and restoration. Restoration Ecology 11:185-197.

Benninger-Truax, M., J.L. Vankat, and R.L. Schaefer. 1992. Trail corridors as habitat and conduits for movement of plant species in Rocky Mountain National Park, Colorado, USA. Landscape Ecology 6:269-278.

Burke, M.J.W., And J.P. Grime. 1996. An experimental study of plant community invasibility. Ecology 77 : 776-790.

Burnside, O.C., R.G. Wilson, S. Weisberg, and K.G. HubBard. 1996. Seed longevity of 41 weed species buried 17 years in eastern and western Nebraska. Weed Science 44:74-86.

Campbell, J.E., and D.J. Gibson. 2001. The effect of seeds of exotic species transported via horse dung on vegetation along trail corridors. Plant Ecology 157: 23-35.

Clifford, H.T. 1956. Seed dispersal on footwear. Proceedings of the Botanical Society of the British Isles 2:129-131.

Coffin, D.P., and W.K. Lauenroth. 1989. Spatial and temporal variation in the seed bank of a semiarid grassland American Journal of Botany 76:53-58.
D’Antonio, C.M., And P.M. Vitousek. 1992. Biological invasions by exotic grasses, the grass/fire cycle, and global change. Annual Review of Ecology and Systematics 23:63-87.

DaubenmiRe, R. 1959. A canopy-coverage method of vegetational analysis. Northwest Science 33:43-64.

Davis, M.A., J.P. Grime, And K. Thompson. 2000. Fluctuating resources in plant communities: a general theory of invasibility. Journal of Ecology 88:528-534.

Dickens, S.J.M., F. Gerhardt, and S.K. Collinge. 2005. Recreational portage trails as corridors facilitating non-native plant invasions of the Boundary Waters Canoe Area Wilderness (USA). Conservation Biology 19:1653-1657.

GowER, S.T. 2008. Are horses responsible for introducing non-native plants along forest trails in the eastern United States? Forest Ecology and Management 256:997-1003.

HobBs, R.J., And L.F. Huenneke. 1992. Disturbance, diversity, and invasion: implications for conservation. Conservation Biology 6:324-337.

Hodkinson, D.J., and K. Thomspon. 1997. Plant dispersal: the role of man. Journal of Applied Ecology 34:1484-1496.

Honu, Y.A.K., And D.J. Gibson. 2008. Patterns of invasion: trends in abundance of understory vegetation, seed rain, and seed bank from forest edge to interior. Natural Areas Journal 28:228-239.

Humphrey, L.D., AND E.W. SCHuPp. 2001. Seed banks of Bromus tectorum-dominated communities in the Great Basin. Western North American Naturalist 61: 85-92.

Jalili, A., B. Hamzeh'ee, Y. Asri, A. Shirvany, S. YazDani, M. Khoshnevis, F. Zarrinkamar, M.A. GHaHRamani, R. Safavi, S. Shaw, ET al. 2003. Soil seed banks in the Arasbaran Protected Area of Iran and their significance for conservation management. Biological Conservation 109:425-431.

Krebs, C.J. 1989. Ecological methodology. Harper and Row, New York, NY.

Larson, D.L., P.J. Anderson, and W. Newton. 2001. Alien plant invasion in mixed-grass prairie: effects of vegetation type and anthropogenic disturbance. Ecological Applications 11:128-141.

LECK, M.A., V.T. PARKER, AND R.L. Simpson. 1989. Ecology of soil seed banks. Academic Press, San Diego, CA.

LONSDALE, W.M. 1999. Global patterns of plant invasions and the concept of invasibility. Ecology 80:1522-1536.

Maccherini, S., AND V. DE Dominicis. 2003. Germinable soil seed-bank of former grassland converted to coniferous plantation. Ecological Research 18:739-751.

Mack, R.N. 2005. Predicting the identity of plant invaders: future contributions from horticulture. Hortscience 40:1168-1174.

MaCK, R.N., AND W.M. LONSDALE. 2001. Humans as global plant dispersers: getting more than we bargained for. BioScience 51:95-102

Marler, M. 2000. A survey of exotic plants in federal wilderness areas. USDA Forest Service Proceedings RMRS-P-15 5:318-327.

Mount, A., And C.M. Pickering. 2009. Testing the capacity of clothing to act as a vector for non-native seed in protected areas. Journal of Environmental Management 91:168-179.

PanetTA, F.D., AND A.J.M. Hopkins. 1993. Weeds in corridors: invasion and management. Pages 341351 in D.A. Saunders and R.J. Hobbs, editors, Nature 
conservation 2: the role of corridors. University of Minnesota, Minneapolis, MN

Pauchard, A., And P.B. Alaback. 2004. Influence of elevation, land use, and landscape context on patterns of alien plant invasions along roadsides in protected areas of south-central Chile. Conservation Biology 18:238-248.

Pickering, C.M., W. Hill, D. Newsome, and Y.-F. LEUNG. 2010. Comparing hiking, mountain biking and horse riding impacts on vegetation and soils in Australia and the United States of America. Journal of Environmental Management 91:551-562.

Potito, A.P., AND S.W. BEATTY. 2005. Impacts of recreation trails on exotic and ruderal species distribution in grassland areas along the Colorado Front Range. Environmental Management 36:230-236.

Pysek, P., V. Jarosk, and T. Kucera. 2002. Patterns of invasion in temperate nature reserves. Biological Conservation 104:13-24.

Quinn, L.D., M. Kolipinski, V.R. Coelho, B. Davis, J.-M. Vianney, O. Batjargal, M. Alas, and S. GHosh. 2008 Germination of invasive plant seeds after digestion by horses in California. Natural Areas Journal 28: 356-362.

Quinn, L.D., A. Quinn, M. Kolipinski, B. Davis, C. Berto, M. Orcholski, and S. Ghosh. 2010. Role of horses as potential vectors of non-native plant invasion: an overview. Natural Areas Journal 30:408-416.

Rubino, D.L., C.E. Williams, and W.J. Moriarity. 2002. Herbaceous layer contrast and alien plant occurrence in utility corridors and riparian forests of the Allegheny High Plateau. Journal of the Torrey Botanical Society 129:125-135.

Salisbury, S.E. 1961. Weeds and aliens. Collins, London.

[SAS] Statistical Analysis System. 2001. System for Windows. Version 8.02 of the SAS System for Win- dows. Copyright 1999-2001, SAS Institute, Inc., Cary, NC.

Stroh, E.D., And M.A. Struckhoff. 2009. Exotic plant species associations with horse trails, old roads, and intact native communities in the Missouri Ozarks. Natural Areas Journal 29:50-56.

Thompson, K. 1987. Seeds and seed banks. New Phytologist 106:23-34.

Thompson, K., AND J.P. GRIME. 1979. Seasonal variation in the seed banks of herbaceous species in ten contrasting habitats. Journal of Ecology 67:893-921.

Tyser, R.W., AND C.A. WorLEy. 1992. Alien flora in grasslands adjacent to road and trail corridors in Glacier National Park, Montana (USA). Conservation Biology 6:253-262.

Vilì, M., J. PinO, AND X. Font. 2007. Regional assessment of plant invasions across different habitat types. Journal of Vegetation Science 18:35-42.

Vitousek, P.M. 1990. Biological invasions and ecosystem processes: towards an integration of population biology and ecosystem studies. Oikos 57:7-13.

Weber, W.A., And R.C. Wittmann. 2001a. Colorado flora: eastern slope. University Press of Colorado, Boulder. 2001b. Colorado flora: western slope. University Press of Colorado, Boulder, CO.

Wells, F.H., And W.K. Lauenroth. 2007. The potential for horses to disperse alien plants along recreational trails. Rangeland Ecology and Management 60: 574-577.

Received 16 November 2011 Accepted 29 July 2012 
ApPEndix 1. Attributes of plant species at trailheads. $\mathrm{B}=$ Booth, $\mathrm{G}=$ Gore, $\mathrm{Pr}=$ Piney River, $\mathrm{P}=\mathrm{Pitkin}, \mathrm{E}=\mathrm{East}$ Portal, $\mathrm{V}=$ Buchanan, $\mathrm{W}=$ West Branch, $\mathrm{F}=$ Fish, $\mathrm{H}=$ Horsetooth, $\mathrm{L}=$ Wells Gulch, $\mathrm{Y}=$ Youngs Gulch.

\begin{tabular}{|c|c|c|c|c|}
\hline Species name & Location & $\begin{array}{l}\text { Trail and } \\
\text { position }\end{array}$ & $\%$ Cover & $\begin{array}{l}\text { Number of } \\
\text { seedlings }\end{array}$ \\
\hline \multicolumn{5}{|l|}{ Alien Species } \\
\hline \multirow[t]{3}{*}{ Agropyron cristatum (L.) Gaertn. } & White River N.F. & B TH & 9 & - \\
\hline & Lory State Park & L adj. & - & 68 \\
\hline & Arapaho-Roosevelt N.F. & Y adj. & - & 23 \\
\hline Alyssum desertorum Stapf & White River N.F. & Pr TH & 5 & - \\
\hline \multirow[t]{4}{*}{ Amaranthus palmeri Watson } & Arapaho-Roosevelt N.F. & $\mathrm{F}$ adj. & - & 23 \\
\hline & & W adj. & - & 23 \\
\hline & Lory State Park & $\mathrm{L} \mathrm{TH}$ & - & 23 \\
\hline & White River N.F. & Pr adj. & - & 91 \\
\hline \multirow[t]{16}{*}{ Bromus inermis Leyss. } & White River N.F. & B TH & 61 & 113 \\
\hline & & $B$ adj. & 39 & 68 \\
\hline & & G adj. & - & 45 \\
\hline & & Pr TH & 2 & 45 \\
\hline & & Pr adj. & 14 & 113 \\
\hline & Arapaho-Roosevelt N.F. & $\mathrm{VTH}$ & 1 & - \\
\hline & & F TH & 23 & 747 \\
\hline & & F adj. & 63 & 657 \\
\hline & & W TH & 5 & 0 \\
\hline & & W adj. & 4 & 23 \\
\hline & & Y TH & 44 & 113 \\
\hline & & Y adj. & 56 & 408 \\
\hline & Lory State Park & $\mathrm{L} \mathrm{TH}$ & 37 & 929 \\
\hline & & $\mathrm{L}$ adj. & - & 1042 \\
\hline & Horsetooth Mtn. Park & H TH & 68 & 566 \\
\hline & & $\mathrm{H}$ adj. & 63 & 159 \\
\hline \multirow[t]{7}{*}{ Bromus tectorum $\mathrm{L}$. } & White River N.F. & B adj. & - & 68 \\
\hline & Arapaho-Roosevelt N.F. & Y TH & - & 317 \\
\hline & & Y adj. & - & 204 \\
\hline & Lory State Park & L TH & - & 4371 \\
\hline & & $\mathrm{L}$ adj. & - & 5367 \\
\hline & Horsetooth Mtn. Park & H TH & - & 249 \\
\hline & & $\mathrm{H}$ adj. & - & 181 \\
\hline Camelina microcarpa DC. & Arapaho-Roosevelt N.F. & W TH & 1 & - \\
\hline \multirow[t]{6}{*}{ Capsella bursa-pastoris (L.) Medik. } & White River N.F. & Pr TH & 5 & 362 \\
\hline & & Pr adj. & - & 23 \\
\hline & & $\mathrm{G} \mathrm{TH}$ & - & 45 \\
\hline & Arapaho-Roosevelt N.F. & Y adj. & - & 23 \\
\hline & & W TH & 3 & 272 \\
\hline & & W adj. & - & 45 \\
\hline \multirow[t]{4}{*}{ Chenopodium album $\mathrm{L}$. } & White River N.F. & B adj. & - & 23 \\
\hline & Arapaho-Roosevelt N.F. & $\mathrm{F}$ adj. & - & 45 \\
\hline & & Y TH & - & 113 \\
\hline & & W TH & 0.25 & - \\
\hline \multirow[t]{6}{*}{ Cirsium arvense (L.) Scop. } & White River N.F. & B TH & 11 & - \\
\hline & & B adj. & 2 & 23 \\
\hline & & G TH & 4 & - \\
\hline & & G adj. & 9 & - \\
\hline & Arapaho-Roosevelt N.F. & $\mathrm{F}$ adj. & - & 45 \\
\hline & & Y TH & - & 113 \\
\hline Cirsium vulgare (Savi) Ten. & White River N.F. & G TH & 6 & - \\
\hline \multirow[t]{4}{*}{ Convolvulus arvensis $\mathrm{L}$. } & Arapaho-Roosevelt N.F. & F TH & 1 & - \\
\hline & & Y adj. & 9 & - \\
\hline & Lory State Park & L TH & 8 & - \\
\hline & & $\mathrm{L}$ adj. & - & 23 \\
\hline \multirow[t]{5}{*}{ Conyza schiedeana (Lessing) Cronquist } & White River N.F. & G adj. & - & 23 \\
\hline & Arapaho-Roosevelt N.F. & V TH & - & 23 \\
\hline & & $\mathrm{F}$ & - & 23 \\
\hline & Horsetooth Mtn. Park & H TH & - & 679 \\
\hline & & $\mathrm{H}$ adj. & - & 68 \\
\hline \multirow{2}{*}{ Dactylis glomerata $\mathrm{L}$. } & White River N.F. & В TH & 11 & 340 \\
\hline & & B adj. & 16 & - \\
\hline
\end{tabular}


Appendix 1. Continued. $\mathrm{B}=$ Booth, $\mathrm{G}=$ Gore, $\mathrm{Pr}=$ Piney River, $\mathrm{P}=$ Pitkin, $\mathrm{E}=$ East Portal, $\mathrm{V}=\mathrm{Buchanan}, \mathrm{W}=$ West Branch, $\mathrm{F}=$ Fish, $\mathrm{H}=$ Horsetooth, $\mathrm{L}=$ Wells Gulch, $\mathrm{Y}=$ Youngs Gulch.

\begin{tabular}{|c|c|c|c|c|}
\hline Species name & Location & $\begin{array}{l}\text { Trail and } \\
\text { position }\end{array}$ & $\%$ Cover & $\begin{array}{c}\text { Number of } \\
\text { seedlings }\end{array}$ \\
\hline & & G TH & 9 & 23 \\
\hline & & G adj. & 28 & 23 \\
\hline & & Pr TH & 2 & - \\
\hline & & Pr adj. & 0.25 & - \\
\hline \multirow[t]{5}{*}{ Erodium cicutarium (L.) L'Hériter } & White River N.F. & B TH & - & 68 \\
\hline & & $B$ adj. & - & 23 \\
\hline & & Pr adj. & - & 91 \\
\hline & Arapaho-Roosevelt N.F. & Y TH & - & 181 \\
\hline & & Y adj. & - & 1019 \\
\hline \multirow[t]{2}{*}{ Gnaphalium uliginosum L. } & White River N.F. & Pr adj. & - & 45 \\
\hline & Arapaho-Roosevelt N.F. & V TH & - & 23 \\
\hline \multirow[t]{2}{*}{ Lepidotheca suaveolens Nuttall. } & White River N.F. & $\operatorname{Pr} \mathrm{TH}$ & - & 91 \\
\hline & Arapaho-Roosevelt N.F. & F TH & - & 45 \\
\hline Linaria vulgaris Miller & White River N.F. & B adj. & - & 23 \\
\hline \multirow[t]{2}{*}{ Lonicera morrowii Gray } & White River N.F. & G TH & 9 & - \\
\hline & & G adj. & 1 & - \\
\hline Malva neglecta Wallroth & Arapaho-Roosevelt N.F. & Y adj. & - & 23 \\
\hline \multirow[t]{3}{*}{ Medicago lupulina $\mathrm{L}$. } & White River N.F. & B adj. & 1 & - \\
\hline & & G adj. & 1 & - \\
\hline & Arapaho-Roosevelt N.F. & F TH & 5 & - \\
\hline \multirow[t]{5}{*}{ Medicago sativa $\mathrm{L}$. } & White River N.F. & B TH & - & 23 \\
\hline & Arapaho-Roosevelt N.F. & Y TH & & 23 \\
\hline & & Y adj. & 18 & 23 \\
\hline & & W TH & 9 & - \\
\hline & Lory State Park & L TH & 1 & - \\
\hline $\begin{array}{l}\text { Melandrium dioicum (L.) Cosson \& } \\
\text { Germain }\end{array}$ & White River N.F. & B TH & - & 113 \\
\hline \multirow{4}{*}{ Melilotus officinalis (L.) Lam. } & White River N.F. & B adj. & 1 & 113 \\
\hline & Arapaho-Roosevelt N.F. & F TH & 12 & 23 \\
\hline & & Y TH & - & 23 \\
\hline & & Y adj. & - & 294 \\
\hline Nasturtium officinale R. Brown & Arapaho-Roosevelt N.F. & $\mathrm{V}$ TH & - & 91 \\
\hline \multirow[t]{5}{*}{ Phleum pratense $\mathrm{L}$. } & White River N.F. & G TH & 9 & - \\
\hline & & G adj. & 2 & - \\
\hline & & Pr TH & 4 & - \\
\hline & & Pr adj. & 12 & - \\
\hline & Arapaho-Roosevelt N.F. & V TH & 2 & - \\
\hline \multirow[t]{4}{*}{ Plantago major L. } & White River N.F. & G adj. & 0.25 & 45 \\
\hline & & Pr TH & - & 23 \\
\hline & Arapaho-Roosevelt N.F. & V TH & - & 23 \\
\hline & & V adj. & 5 & 23 \\
\hline \multirow[t]{8}{*}{ Pоа аппиа $\mathrm{L}$. } & White River N.F. & B TH & - & 91 \\
\hline & & G TH & - & 45 \\
\hline & & Pr TH & - & 91 \\
\hline & & Pr adj. & - & 1291 \\
\hline & Arapaho-Roosevelt N.F. & F TH & - & 136 \\
\hline & & V TH & - & 6432 \\
\hline & & V adj. & - & 498 \\
\hline & Lory State Park & $\mathrm{L}$ adj. & - & 91 \\
\hline \multirow[t]{6}{*}{ Poa compressa L. } & White River N.F. & B adj. & - & 906 \\
\hline & Arapaho-Roosevelt N.F. & $\mathrm{F} \mathrm{TH}$ & - & 136 \\
\hline & & V TH & - & 113 \\
\hline & & V adj. & - & 1540 \\
\hline & Lory State Park & $\mathrm{L} \mathrm{TH}$ & - & 91 \\
\hline & & $\mathrm{L}$ adj. & - & 23 \\
\hline \multirow[t]{4}{*}{ Poa trivialis $\mathrm{L}$. } & White River N.F. & В TH & 15 & - \\
\hline & & B adj. & 2 & - \\
\hline & & Pr TH & 16 & - \\
\hline & & Pr adj. & 6 & - \\
\hline \multirow{2}{*}{ Polygonum arenastrum Jord. ex Boreau } & White River N.F. & B TH & 1 & - \\
\hline & & G TH & 1 & - \\
\hline
\end{tabular}


Appendix 1. Continued. $\mathrm{B}=$ Booth, $\mathrm{G}=$ Gore, $\mathrm{Pr}=$ Piney River, $\mathrm{P}=$ Pitkin, $\mathrm{E}=$ East Portal, $\mathrm{V}=\mathrm{Buchanan}, \mathrm{W}=$ West Branch, $\mathrm{F}=$ Fish, $\mathrm{H}=$ Horsetooth, $\mathrm{L}=$ Wells Gulch, $\mathrm{Y}=$ Youngs Gulch.

Rumex crispis $\mathrm{L}$.

Sonchus asper (L.) Hill

Sonchus oleraceus $\mathrm{L}$.

Spergularia rubra (L.) J.\& K. Presl

Taraxacum officinale G.H. Weber ex Wiggers

Location

Arapaho-Roosevelt N.F

Arapaho-Roosevelt N.F

White River N.F.

Arapaho-Roosevelt N.F.

Lory State Park

Horsetooth Mtn. Park

Arapaho-Roosevelt N.F.

White River N.F.

Arapaho-Roosevelt N.F.

White River N.F

Arapaho-Roosevelt N.F.

Lory State Park

Thinopyrum intermedium (Host) Barkworth \& D.R. Dewey

Thlaspi arvense $\mathrm{L}$.

Tragopogon pratensis $\mathrm{L}$.

Trifolium repens $\mathrm{L}$.

Verbascum thapsus L.

Verbena bracteata Lagasca \& Rodrigues

Native Species

Achillea lanulosa Nutt.

\begin{tabular}{|c|c|c|}
\hline $\begin{array}{l}\text { Trail and } \\
\text { position }\end{array}$ & $\%$ Cover & $\begin{array}{l}\text { Number of } \\
\text { seedlings }\end{array}$ \\
\hline G adj. & - & 45 \\
\hline Pr TH & - & 23 \\
\hline V TH & 3 & - \\
\hline V adj. & 0.25 & 23 \\
\hline F TH & 3 & - \\
\hline W TH & 3 & 181 \\
\hline Y TH & 4 & 23 \\
\hline V TH & 1 & - \\
\hline B TH & - & 68 \\
\hline G TH & - & 23 \\
\hline Y TH & - & 45 \\
\hline Y adj. & - & 23 \\
\hline L adj. & 1 & 23 \\
\hline H TH & - & 181 \\
\hline Y TH & - & 23 \\
\hline Pr TH & - & 2084 \\
\hline Pr adj. & - & 1178 \\
\hline V TH & 1 & 566 \\
\hline W TH & 0.25 & 6885 \\
\hline В TH & 1 & 136 \\
\hline G TH & 3 & 272 \\
\hline G adj. & 11 & 23 \\
\hline Pr TH & 5 & 136 \\
\hline Pr adj. & 3 & - \\
\hline V TH & 3 & - \\
\hline V adj. & 2 & 45 \\
\hline F TH & 2 & 294 \\
\hline F adj. & 7 & - \\
\hline W TH & 13 & 91 \\
\hline W adj. & 5 & 23 \\
\hline Y TH & 1 & - \\
\hline L TH & - & 23 \\
\hline L adj. & - & 45 \\
\hline Y adj. & 4 & - \\
\hline W TH & 0.25 & - \\
\hline G TH & 5 & - \\
\hline V TH & 11 & - \\
\hline F TH & 0.25 & - \\
\hline B TH & - & 362 \\
\hline B adj. & 3 & 385 \\
\hline Y TH & - & 1676 \\
\hline Y adj. & - & 3963 \\
\hline L TH & - & 204 \\
\hline L adj. & - & 91 \\
\hline H TH & - & 23 \\
\hline $\mathrm{H}$ adj. & - & 159 \\
\hline Y adj. & - & 91 \\
\hline L TH & - & 2831 \\
\hline L adj. & - & 136 \\
\hline H TH & - & 204 \\
\hline $\mathrm{H}$ adj. & - & 476 \\
\hline G TH & 4 & - \\
\hline G adj. & 2 & - \\
\hline Pr TH & 2 & - \\
\hline Pr adj. & 9 & - \\
\hline V TH & 2 & - \\
\hline V adj. & 2 & - \\
\hline F TH & 3 & - \\
\hline $\mathrm{F}$ adj. & 2 & - \\
\hline
\end{tabular}


Appendix 1. Continued. $\mathrm{B}=$ Booth, $\mathrm{G}=$ Gore, $\mathrm{Pr}=$ Piney River, $\mathrm{P}=$ Pitkin, $\mathrm{E}=$ East Portal, $\mathrm{V}=\mathrm{Buchanan}, \mathrm{W}=$ West Branch, $\mathrm{F}=$ Fish, $\mathrm{H}=$ Horsetooth, $\mathrm{L}=$ Wells Gulch, $\mathrm{Y}=$ Youngs Gulch.

\begin{tabular}{|c|c|c|c|c|}
\hline Species name & Location & $\begin{array}{l}\text { Trail and } \\
\text { position }\end{array}$ & $\%$ Cover & $\begin{array}{l}\text { Number of } \\
\text { seedlings }\end{array}$ \\
\hline & & W TH & 2 & - \\
\hline \multirow[t]{5}{*}{ Achnatherum nelsonii (Scribn.) Barkworth } & White River N.F. & G TH & 0.25 & - \\
\hline & Arapaho-Roosevelt N.F. & V TH & 1 & - \\
\hline & & V adj. & 1 & - \\
\hline & & W TH & 3 & - \\
\hline & & W adj. & 2 & - \\
\hline \multirow{4}{*}{ Agrostis scabra Willd. } & White River N.F. & Pr adj. & 0.25 & - \\
\hline & & G adj. & 0.25 & 68 \\
\hline & Arapaho-Roosevelt N.F. & $\mathrm{V}$ TH & - & 91 \\
\hline & Lory State Park & L TH & - & 181 \\
\hline \multirow[t]{2}{*}{ Allium cernuum Roth } & White River N.F. & $\operatorname{Pr} \mathrm{TH}$ & 0.25 & - \\
\hline & & Pr adj. & 1 & - \\
\hline \multirow{2}{*}{ Amaranthus albus L. } & White River N.F. & B adj. & 9 & - \\
\hline & & G adj. & 4 & - \\
\hline \multirow[t]{2}{*}{ Ambrosia psilostachya DC. } & Horsetooth Mtn. Park & H TH & 1 & - \\
\hline & Lory State Park & $\mathrm{L}$ adj. & 6 & - \\
\hline Amerosedum lanceolatum (Torr.) & White River N.F. & Pr TH & 1 & - \\
\hline \multirow[t]{2}{*}{ A.\& D. Löve } & Arapaho-Roosevelt N.F. & V adj. & 2 & - \\
\hline & & W adj. & 2 & - \\
\hline Androsace occidentalis Pursh & Arapaho-Roosevelt N.F. & W TH & 0.25 & - \\
\hline \multirow[t]{6}{*}{ Androsace septentrionalis L. } & White River N.F. & Pr adj. & - & 91 \\
\hline & & F adj. & - & 23 \\
\hline & & $\mathrm{V}$ TH & - & 23 \\
\hline & & W TH & - & 340 \\
\hline & & W adj. & 1 & 996 \\
\hline & Horsetooth Mtn. Park & $\mathrm{H}$ adj. & - & 68 \\
\hline \multirow[t]{3}{*}{ Antennaria corymbosa E. Nels. } & White River N.F. & B TḦ & 1 & - \\
\hline & & G adj. & 1 & - \\
\hline & & $\operatorname{Pr} \mathrm{TH}$ & 1 & - \\
\hline \multirow{2}{*}{ Antennaria rosea Greene } & Arapaho-Roosevelt N.F. & V TH & 1 & - \\
\hline & & V adj. & 1 & - \\
\hline \multirow{7}{*}{ Arabis L. } & White River N.F. & G TH & 0.25 & - \\
\hline & & $\operatorname{Pr} \mathrm{TH}$ & 0.25 & - \\
\hline & & Pr adj. & 0.25 & - \\
\hline & Arapaho-Roosevelt N.F. & $\mathrm{V}$ TH & 1 & - \\
\hline & & V adj. & 1 & - \\
\hline & & $\mathrm{F}$ adj. & - & 23 \\
\hline & & Y TH & - & 45 \\
\hline \multirow[t]{6}{*}{ Artemisia frigida Willd. } & Arapaho-Roosevelt N.F. & V adj. & 2 & - \\
\hline & & $\mathrm{F}$ adj. & - & 45 \\
\hline & & Y TH & 1 & 23 \\
\hline & & Y adj. & - & 23 \\
\hline & Lory State Park & $\mathrm{L}$ adj. & 4 & - \\
\hline & Horsetooth Mtn. Park & H TH & - & 23 \\
\hline \multirow[t]{4}{*}{ Artemisia ludoviciana Nutt. } & Lory State Park & L TH & 3 & - \\
\hline & Horsetooth Mtn. Park & H TH & - & 23 \\
\hline & & $\mathrm{H}$ adj. & 2 & 317 \\
\hline & Arapaho-Roosevelt N.F. & Y adj. & - & 23 \\
\hline Artemisia tridentata Nutt. & Arapaho-Roosevelt N.F. & W TH & 9 & - \\
\hline Asclepias macrotis Torr. & Horsetooth Mtn. Park & H TH & 3 & - \\
\hline \multirow[t]{2}{*}{ Aster adscendens Lindl. } & Lory State Park & L TH & 1 & - \\
\hline & & $\mathrm{L}$ adj. & 1 & - \\
\hline Astragalus laxmannii Jacq. & Arapaho-Roosevelt N.F. & F TH & 0.5 & - \\
\hline \multirow[t]{8}{*}{ Aster L. } & White River N.F. & B adj. & - & 136 \\
\hline & & G TH & 0.25 & - \\
\hline & & Pr adj. & - & 23 \\
\hline & Arapaho-Roosevelt N.F. & F TH & 0.5 & 23 \\
\hline & & $\mathrm{V}$ TH & - & 23 \\
\hline & Lory State Park & L TH & 2 & - \\
\hline & & $\mathrm{L}$ adj. & 11 & 91 \\
\hline & Horsetooth Mtn. Park & H TH & 1 & - \\
\hline
\end{tabular}


Appendix 1. Continued. $\mathrm{B}=$ Booth, $\mathrm{G}=$ Gore, $\mathrm{Pr}=$ Piney River, $\mathrm{P}=$ Pitkin, $\mathrm{E}=$ East Portal, $\mathrm{V}=\mathrm{Buchanan}, \mathrm{W}=$ West Branch, $\mathrm{F}=$ Fish, $\mathrm{H}=$ Horsetooth, $\mathrm{L}=$ Wells Gulch, $\mathrm{Y}=$ Youngs Gulch.

\begin{tabular}{|c|c|c|c|c|}
\hline Species name & Location & $\begin{array}{l}\text { Trail and } \\
\text { position }\end{array}$ & $\%$ Cover & $\begin{array}{l}\text { Number of } \\
\text { seedlings }\end{array}$ \\
\hline Bassia sieversiana (Pallas) Weber & Arapaho-Roosevelt N.F. & Y TH & - & 23 \\
\hline Boechera drummondii (Gray) & Arapaho-Roosevelt N.F. & V TH & 1 & - \\
\hline A.\& D. Löve & & V adj. & 2 & - \\
\hline \multirow[t]{3}{*}{ Bromus carinatus Hook. \& Arn. } & White River N.F. & G TH & 2 & - \\
\hline & & G adj. & 2 & - \\
\hline & & Pr adj. & 1 & - \\
\hline \multirow{2}{*}{ Bromus ciliatus L. } & Arapaho-Roosevelt N.F. & V adj. & 1 & - \\
\hline & & F TH & - & 23 \\
\hline Cactaceae Jussieu & Lory State Park & L TH & - & 23 \\
\hline Campanula rotundifolia $\mathrm{L}$. & Arapaho-Roosevelt N.F. & Y TH & 0.25 & - \\
\hline \multirow[t]{8}{*}{ Carex $\mathrm{L}$} & White River N.F. & G TH & - & 45 \\
\hline & & G adj. & - & 68 \\
\hline & & Pr TH & - & 249 \\
\hline & & Pr adj. & 4 & 498 \\
\hline & Arapaho-Roosevelt N.F. & $\mathrm{VTH}$ & 24 & - \\
\hline & & V adj. & 10 & 45 \\
\hline & & Y adj. & & 23 \\
\hline & Horsetooth Mtn. Park & $\mathrm{H} \mathrm{TH}$ & & 23 \\
\hline Cerastium L. & West Branch & off & 7 & - \\
\hline Cercocarpus montanus Raf. & Arapaho-Roosevelt N.F. & Y TH & 1 & - \\
\hline Chamerion angustifolium (L.) Holub & White River N.F. & G adj. & 6 & - \\
\hline Chenopodium berlandieri Moq. & White River N.F. & G TH & 0.25 & - \\
\hline Chrysothamnus nauseosus (Pallas ex & Arapaho-Roosevelt N.F. & Y TH & 1 & - \\
\hline \multirow[t]{2}{*}{ Pursh) Britt. } & & Y adj. & 2 & - \\
\hline & Horsetooth Mtn. Park & H TH & 5 & - \\
\hline Cirsium Mill. & White River N.F. & Pr TH & - & 23 \\
\hline Cirsium centaureae (Rydb.) K. Schum. & Arapaho-Roosevelt N.F. & F adj. & 1 & - \\
\hline \multirow[t]{3}{*}{ Cirsium eatonii (Gray) B.L. Robins. } & White River N.F. & B adj. & 2 & - \\
\hline & & G TH & - & 23 \\
\hline & & G adj. & 1 & - \\
\hline \multirow[t]{2}{*}{ Clematis ligusticifolia Nutt. } & Arapaho-Roosevelt N.F. & Y TH & 4 & - \\
\hline & & Y adj. & 20 & 45 \\
\hline \multirow[t]{3}{*}{ Collomia linearis Nutt. } & White River N.F. & Pr TH & 1 & - \\
\hline & Arapaho-Roosevelt N.F. & V adj. & 1 & - \\
\hline & & W TH & 1 & - \\
\hline \multirow[t]{2}{*}{ Dasiphora floribunda (Pursh) Kartesz } & White River N.F. & Pr TH & 1 & - \\
\hline & & Pr adj. & 6 & - \\
\hline Elymus canadensis L. & White River N.F. & G adj. & 5 & - \\
\hline \multirow{3}{*}{$\begin{array}{l}\text { Elymus trachycaulus (Link) Gould } \\
\text { ex Shinners }\end{array}$} & & & & \\
\hline & Arapaho-Roosevelt N.F. & F TH & 1 & - \\
\hline & & W TH & 13 & - \\
\hline Epilobium L. & White River N.F. & Pr adj. & 3 & - \\
\hline Epilobium brachycarpum Presl. & White River N.F. & $\mathrm{B}$ TH & - & 23 \\
\hline \multirow[t]{2}{*}{ Epilobium ciliatum Raf. } & Arapaho-Roosevelt N.F. & $\mathrm{V} \mathrm{TH}$ & 3 & 45 \\
\hline & & Y adj. & - & 226 \\
\hline \multirow[t]{7}{*}{ Erigeron L. } & White River N.F. & B adj. & 2 & - \\
\hline & & G TH & 2 & - \\
\hline & & G adj. & 3 & - \\
\hline & & Pr TH & 2 & - \\
\hline & & Pr adj. & 2 & - \\
\hline & Arapaho-Roosevelt N.F. & W adj. & 3 & - \\
\hline & & Y adj. & - & 45 \\
\hline Erigeron compositus Pursh & Arapaho-Roosevelt N.F. & V adj. & 2 & - \\
\hline Erigeron divergens Torr. \& Gray & Lory State Park & L TH & 2 & - \\
\hline Erigeron flagellaris Gray & Lory State Park & $\mathrm{L}$ adj. & - & 68 \\
\hline \multirow[t]{6}{*}{ Erigeron formosissimus Greene } & White River N.F. & B adj. & 2 & - \\
\hline & & G TH & 1 & - \\
\hline & & G adj. & 3 & - \\
\hline & & Pr TH & 5 & - \\
\hline & & Pr adj. & 7 & - \\
\hline & Arapaho-Roosevelt N.F. & $\mathrm{V} \mathrm{TH}$ & 1 & - \\
\hline
\end{tabular}


Appendix 1. Continued. $\mathrm{B}=$ Booth, $\mathrm{G}=$ Gore, $\mathrm{Pr}=$ Piney River, $\mathrm{P}=$ Pitkin, $\mathrm{E}=$ East Portal, $\mathrm{V}=\mathrm{Buchanan}, \mathrm{W}=$ West Branch, $\mathrm{F}=$ Fish, $\mathrm{H}=$ Horsetooth, $\mathrm{L}=$ Wells Gulch, $\mathrm{Y}=$ Youngs Gulch.

\begin{tabular}{|c|c|c|c|c|}
\hline Species name & Location & $\begin{array}{l}\text { Trail and } \\
\text { position }\end{array}$ & $\%$ Cover & $\begin{array}{l}\text { Number of } \\
\text { seedlings }\end{array}$ \\
\hline & & V adj. & 7 & - \\
\hline Erigeron speciosus (Lindl.) DC. & Arapaho-Roosevelt N.F. & F TH & 9 & - \\
\hline \multirow[t]{2}{*}{ Eragrostis trichodes (Nutt.) Wood } & White River N.F. & $\operatorname{Pr} \mathrm{TH}$ & 1 & - \\
\hline & & Pr adj. & 4 & - \\
\hline Eriogonum umbellatum Torr. & Arapaho-Roosevelt N.F. & W adj. & 4 & - \\
\hline Festuca arizonica Vasey & White River N.F. & G adj. & 1 & - \\
\hline \multirow[t]{2}{*}{ Festuca idahoensis Elmer } & Arapaho-Roosevelt N.F. & F adj. & 57 & - \\
\hline & & W adj. & 33 & - \\
\hline Festuca rubra L. & Arapaho-Roosevelt N.F. & F TH & 16 & - \\
\hline \multirow[t]{2}{*}{ Festuca saximontana Rydb. } & Arapaho-Roosevelt N.F. & V adj. & 1 & - \\
\hline & & W TH & 14 & - \\
\hline \multirow[t]{7}{*}{ Fragaria virginiana Duchesne } & White River N.F. & G TH & - & 91 \\
\hline & & G adj. & 3 & - \\
\hline & & Pr adj. & 5 & - \\
\hline & Arapaho-Roosevelt N.F. & $\mathrm{V} \mathrm{TH}$ & - & 45 \\
\hline & & $\mathrm{V}$ adj. & - & 23 \\
\hline & & F adj. & - & 23 \\
\hline & & Y TH & - & 23 \\
\hline Frasera speciosa Douglas & White River N.F. & Pr adj. & 1 & - \\
\hline \multirow{5}{*}{$\begin{array}{l}\text { Galium septentrionale Roemer \& } \\
\text { J.A. Schultes }\end{array}$} & White River N.F. & B TH & 1 & - \\
\hline & & Pr adj. & 0.25 & - \\
\hline & Arapaho-Roosevelt N.F. & $\mathrm{V} \mathrm{TH}$ & 2 & - \\
\hline & & V adj. & 2 & - \\
\hline & & $\mathrm{F}$ adj. & 1 & - \\
\hline \multirow[t]{3}{*}{ Geranium richardsonii Fisch. \& Trautv. } & White River N.F. & В ТН & 5 & - \\
\hline & & G TH & 32 & 23 \\
\hline & & G adj. & 7 & - \\
\hline Geum macrophyllum Willd. & White River N.F. & G TH & 2 & - \\
\hline \multirow[t]{2}{*}{ Gnaphalium L. } & Arapaho-Roosevelt N.F. & V adj. & - & 91 \\
\hline & Horsetooth Mtn. Park & H TH & - & 45 \\
\hline Gutierrezia sarothrae (Pursh) Britt. \& & Lory State Park & L TH & 8 & - \\
\hline \multirow[t]{2}{*}{ Rusby } & & $\mathrm{L}$ adj. & 10 & - \\
\hline & Horsetooth Mtn. Park & $\mathrm{H}$ adj. & 4 & - \\
\hline Hedeoma hispidium Pursh. & Horsetooth Mtn. Park & $\mathrm{H}$ adj. & - & 249 \\
\hline Heliomeris multiflora Nutt. & White River N.F. & G TH & 1 & - \\
\hline Heracleum maximum Bartr. & White River N.F. & G TH & 6 & - \\
\hline \multirow[t]{5}{*}{ Heterotheca villosa (Pursh) Shinners } & Arapaho-Roosevelt N.F. & V adj. & 3 & - \\
\hline & & Y TH & - & 113 \\
\hline & Lory State Park & L TH & 2 & 45 \\
\hline & & $\mathrm{L}$ adj. & 1 & 249 \\
\hline & Horsetooth Mtn. Park & $\mathrm{H}$ adj. & - & 91 \\
\hline Hordeum brachyantherum Nevski. & White River N.F. & Pr adj. & 2 & 0 \\
\hline \multirow[t]{4}{*}{ Juncus L. } & White River N.F. & $\operatorname{Pr} \mathrm{TH}$ & 2 & 91 \\
\hline & & Pr adj. & 2 & 544 \\
\hline & Arapaho-Roosevelt N.F. & F TH & - & 23 \\
\hline & & $\mathrm{F}$ adj. & 2 & 91 \\
\hline \multirow[t]{3}{*}{ Juncus balticus Willd. } & White River N.F. & Pr TH & - & 566 \\
\hline & & Pr adj. & - & 4099 \\
\hline & Arapaho-Roosevelt N.F. & V TH & 2 & - \\
\hline Juniperus communis $\mathrm{L}$. & White River N.F. & G adj. & 2 & - \\
\hline Juniperus scopulorum Sarg. & Arapaho-Roosevelt N.F. & V adj. & 2 & - \\
\hline Lepidium densiflorum Schrad. & White River N.F. & G TH & 1 & - \\
\hline \multirow[t]{2}{*}{ Liatris punctata Hook. } & Horsetooth Mtn. Park & $\mathrm{H}$ adj. & 0.25 & - \\
\hline & Lory State Park & L TH & 1 & - \\
\hline \multirow[t]{2}{*}{ Lupinus argenteus Pursh } & Arapaho-Roosevelt N.F. & F TH & 1 & - \\
\hline & Horsetooth Mtn. Park & Н ТH & 1 & 23 \\
\hline Mahonia repens (Lindl.) G. Don & White River N.F. & B adj. & 1 & - \\
\hline \multirow[t]{3}{*}{ Maianthemum stellatum (L.) Link } & Arapaho-Roosevelt N.F. & V adj. & 2 & - \\
\hline & White River N.F. & Pr adj. & 1 & - \\
\hline & White River N.F. & Pr TH & - & 45 \\
\hline Mimulus glabratus Kunth & White River N.F. & Pr adj. & 1 & 68 \\
\hline
\end{tabular}


Appendix 1. Continued. $\mathrm{B}=$ Booth, $\mathrm{G}=$ Gore, $\mathrm{Pr}=$ Piney River, $\mathrm{P}=$ Pitkin, $\mathrm{E}=$ East Portal, $\mathrm{V}=\mathrm{Buchanan}, \mathrm{W}=$ West Branch, $\mathrm{F}=$ Fish, $\mathrm{H}=$ Horsetooth, $\mathrm{L}=$ Wells Gulch, $\mathrm{Y}=$ Youngs Gulch.

\begin{tabular}{|c|c|c|c|c|}
\hline Species name & Location & $\begin{array}{l}\text { Trail and } \\
\text { position }\end{array}$ & $\%$ Cover & $\begin{array}{l}\text { Number of } \\
\text { seedlings }\end{array}$ \\
\hline \multirow{3}{*}{$\begin{array}{l}\text { Muhlenbergia filiformis (Thurb. ex S. } \\
\text { Wats.) Rydb. }\end{array}$} & White River N.F. & Pr adj. & 2 & 91 \\
\hline & \multirow[t]{2}{*}{ Arapaho-Roosevelt N.F. } & F adj. & - & 91 \\
\hline & & W adj. & - & 45 \\
\hline $\begin{array}{l}\text { Muhlenbergia minutissima (Steudel) } \\
\text { Swallen }\end{array}$ & Arapaho-Roosevelt N.F. & F TH & - & 23 \\
\hline Opuntia polyacantha Haw. & Horsetooth Mtn. Park & $\mathrm{H}$ adj. & 1 & - \\
\hline \multirow[t]{10}{*}{ Pascopyrum smithii (Rydb.) A. Löve } & \multirow[t]{6}{*}{ White River N.F. } & B TH & 2 & - \\
\hline & & B adj. & 0.25 & - \\
\hline & & G TH & 16 & 136 \\
\hline & & G adj. & - & 45 \\
\hline & & Pr TH & 11 & 23 \\
\hline & & Pr adj. & - & 45 \\
\hline & \multirow[t]{3}{*}{ Arapaho-Roosevelt N.F. } & V adj. & 5 & - \\
\hline & & $W$ adj. & 1 & - \\
\hline & & Y adj. & - & 23 \\
\hline & Horsetooth Mtn. Park & $\mathrm{H} \mathrm{TH}$ & 1 & - \\
\hline Penstemon cobaea Nutt. & Arapaho-Roosevelt N.F. & V adj. & 5 & - \\
\hline Pinus contorta Dougl. ex Loud. & White River N.F. & G adj. & 2 & - \\
\hline \multirow[t]{2}{*}{ Pinus ponderosa P.\& C. Lawson } & Arapaho-Roosevelt N.F. & Y adj. & 9 & - \\
\hline & Horsetooth Mtn. Park & $\mathrm{H}$ adj. & - & 23 \\
\hline Poa L. & Lory State Park & L adj. & 21 & - \\
\hline \multirow[t]{14}{*}{ Poa pratensis $\mathrm{L}$. } & \multirow[t]{5}{*}{ White River N.F. } & B TH & - & 272 \\
\hline & & G TH & 10 & 0 \\
\hline & & G adj. & - & 91 \\
\hline & & $\operatorname{Pr} \mathrm{TH}$ & - & 23 \\
\hline & & Pr adj. & - & 204 \\
\hline & \multirow[t]{6}{*}{ Arapaho-Roosevelt N.F. } & V TH & 7 & - \\
\hline & & V adj. & 5 & - \\
\hline & & F TH & 3 & - \\
\hline & & F adj. & - & 136 \\
\hline & & W TH & 20 & 23 \\
\hline & & Y TH & - & 136 \\
\hline & \multirow{2}{*}{ Lory State Park } & $\mathrm{L} \mathrm{TH}$ & - & 430 \\
\hline & & $\mathrm{L}$ adj. & - & 68 \\
\hline & \multirow[t]{5}{*}{ Horsetooth Mtn. Park } & $\mathrm{H}$ adj. & - & 45 \\
\hline \multirow[t]{4}{*}{ Poa secunda J. Presl } & & Pr TH & 3 & - \\
\hline & & Pr adj. & 1 & - \\
\hline & & W TH & 1 & - \\
\hline & & W adj. & 4 & - \\
\hline \multirow[t]{4}{*}{ Polygonum douglasii Greene } & \multirow[t]{3}{*}{ White River N.F. } & G TH & 4 & - \\
\hline & & $\operatorname{Pr} \mathrm{TH}$ & 16 & - \\
\hline & & Pr adj. & 1 & - \\
\hline & Arapaho-Roosevelt N.F. & $W$ adj. & 4 & - \\
\hline \multirow[t]{4}{*}{ Populus angustifolia James } & \multirow[t]{3}{*}{ Arapaho-Roosevelt N.F. } & F TH & - & 23 \\
\hline & & $\mathrm{F}$ adj. & - & 23 \\
\hline & & Y adj. & - & 23 \\
\hline & Horsetooth Mtn. Park & $\mathrm{H}$ adj. & - & 23 \\
\hline Potentilla concinna Richards. & Lory State Park & L TH & 1 & - \\
\hline & & $\mathrm{L}$ adj. & 1 & - \\
\hline Potentilla fissa Nutt. & Arapaho-Roosevelt N.F. & $\mathrm{V} \mathrm{TH}$ & - & 23 \\
\hline Potentilla hippiana Lehm. & Arapaho-Roosevelt N.F. & W TH & 1 & - \\
\hline Potentilla norvegica $\mathrm{L}$. & Arapaho-Roosevelt N.F. & V adj. & 3 & - \\
\hline Potentilla pensylvanica $\mathrm{L}$. & Arapaho-Roosevelt N.F. & F adj. & 1 & 45 \\
\hline Potentilla pulcherrima Lehm. & White River N.F. & $B$ adj. & - & 23 \\
\hline & & G TH & 4 & 181 \\
\hline & & G adj. & - & 23 \\
\hline & & Pr TH & 2 & - \\
\hline & & Pr adj. & 0.25 & 23 \\
\hline & Arapaho-Roosevelt N.F. & W TH & 1 & - \\
\hline & & W adj. & 2 & 45 \\
\hline & Horsetooth Mtn. Park & $\mathrm{H}$ adj. & 1 & - \\
\hline
\end{tabular}


Appendix 1. Continued. $\mathrm{B}=$ Booth, $\mathrm{G}=$ Gore, $\mathrm{Pr}=$ Piney River, $\mathrm{P}=$ Pitkin, $\mathrm{E}=$ East Portal, $\mathrm{V}=\mathrm{Buchanan}, \mathrm{W}=$ West Branch, $\mathrm{F}=$ Fish, $\mathrm{H}=$ Horsetooth, $\mathrm{L}=$ Wells Gulch, $\mathrm{Y}=$ Youngs Gulch.

\begin{tabular}{|c|c|c|c|c|}
\hline Species name & Location & $\begin{array}{l}\text { Trail and } \\
\text { position }\end{array}$ & $\%$ Cover & $\begin{array}{l}\text { Number of } \\
\text { seedlings }\end{array}$ \\
\hline \multirow[t]{2}{*}{ Potentilla rivalis Nutt. } & & $\operatorname{Pr} \mathrm{TH}$ & 3 & - \\
\hline & & Pr adj. & 1 & - \\
\hline $\begin{array}{l}\text { Prunus virginica L. var. melanocarpa } \\
\quad \text { (A. Nels.) Sarg. }\end{array}$ & White River N.F. & B adj. & 4 & - \\
\hline $\begin{array}{l}\text { Pseudocymopterus montanus (Gray) } \\
\text { Coult. \& Rose }\end{array}$ & Arapaho-Roosevelt N.F. & V adj. & 2 & - \\
\hline \multirow[t]{3}{*}{ Psoralidium tenuiflorum (Pursh) Rydb. } & Lory State Park & L TH & 15 & - \\
\hline & & $\mathrm{L}$ adj. & 4 & - \\
\hline & Horsetooth Mtn. Park & H TH & 4 & - \\
\hline \multirow{3}{*}{$\begin{array}{l}\text { Ratibida columnifera (Nutt.) Woot. } \\
\quad \text { \& Standl. }\end{array}$} & Lory State Park & L adj. & 1 & - \\
\hline & Horsetooth Mtn. Park & Н ТН̈ & 1 & - \\
\hline & & $\mathrm{H}$ adj. & 1 & - \\
\hline $\begin{array}{l}\text { Rhus aromatica Ait. ssp. trilobata } \\
\text { (Nutt.) W.A. Weber }\end{array}$ & Arapaho-Roosevelt N.F. & Y TH & 5 & - \\
\hline Ribes cereum Dougl. & Arapaho-Roosevelt N.F. & Y TH & 5 & - \\
\hline \multirow{3}{*}{ Ribes inerme Rydb. } & White River N.F. & G TH & 6 & - \\
\hline & & G adj. & 4 & - \\
\hline & Arapaho-Roosevelt N.F. & Y TH & 1 & - \\
\hline \multirow{4}{*}{ Rosa woodsii Lindl. } & White River N.F. & B adj. & 28 & - \\
\hline & & G adj. & 6 & - \\
\hline & Arapaho-Roosevelt N.F. & $V$ adj. & 7 & - \\
\hline & & Y TḦ & 2 & - \\
\hline \multirow[t]{2}{*}{ Rubus idaeus L. } & White River N.F. & G TH & 4 & - \\
\hline & & G adj. & - & 68 \\
\hline Sagina saginoides (L.) Karstens & White River N.F. & Pr adj. & - & 476 \\
\hline \multirow[t]{2}{*}{ Salix L. } & White River N.F. & G TH & 14 & - \\
\hline & & G adj. & 2 & 23 \\
\hline Sambucus microbotrys Rydb. & White River N.F. & G adj. & - & 23 \\
\hline \multirow[t]{2}{*}{ Saxifraga $\mathrm{L}}$. & Arapaho-Roosevelt N.F. & G TH & - & 113 \\
\hline & Arapaho-Roosevelt N.F. & W adj. & - & 23 \\
\hline Sedum lanceolatum Torr. & Arapaho-Roosevelt N.F. & F TH & - & 23 \\
\hline \multirow[t]{2}{*}{ Senecio eremophilus Richards. } & White River N.F. & B TH & - & 23 \\
\hline & & G TH & - & 23 \\
\hline \multirow[t]{3}{*}{ Senecio spartioides Torr. \& Gray } & Lory State Park & L adj. & - & 23 \\
\hline & Horsetooth Mtn. Park & H TH & - & 45 \\
\hline & & $\mathrm{H}$ adj. & - & 23 \\
\hline Silene antirrhina $\mathrm{L}$. & Horsetooth Mtn. Park & $\mathrm{H}$ adj. & - & 589 \\
\hline \multirow[t]{3}{*}{ Solidago missouriensis Nuttall } & White River N.F. & Pr adj. & 1 & - \\
\hline & Arapaho-Roosevelt N.F. & V TH & 3 & - \\
\hline & & V adj. & 3 & - \\
\hline \multirow[t]{6}{*}{ Sporobolus cryptandrus (Torr.) Gray } & Arapaho-Roosevelt N.F. & Y TH & - & 929 \\
\hline & & Y adj. & - & 861 \\
\hline & Lory State Park & $\mathrm{L} \mathrm{TH}$ & 4 & 883 \\
\hline & & $\mathrm{L}$ adj. & 21 & 996 \\
\hline & Horsetooth Mtn. Park & H TH & - & 294 \\
\hline & & $\mathrm{H}$ adj. & - & 589 \\
\hline Stellaria umbellata Turczaninow & White River N.F. & Pr adj. & - & 23 \\
\hline \multirow[t]{2}{*}{ Symphoricarpos rotundifolius Gray } & White River N.F. & B TH & 1 & - \\
\hline & & B adj. & 4 & - \\
\hline Thalictrum occidentale Gray & White River N.F. & G TH & 4 & - \\
\hline Thermopsis divaricarpa A. Nels. & Arapaho-Roosevelt N.F. & V adj. & 13 & - \\
\hline \multirow[t]{2}{*}{ Tradescantia occidentalis (Britt.) Smyth } & Arapaho-Roosevelt N.F. & W TH & 1 & - \\
\hline & Horsetooth Mtn. Park & H TH & 1 & - \\
\hline \multirow[t]{2}{*}{ Valeriana edulis Nutt. ex Torr. \& Gray } & Arapaho-Roosevelt N.F. & F TH & 1 & - \\
\hline & & F adj. & 1 & - \\
\hline Veronica americana Schwein. ex Benth. & Arapaho-Roosevelt N.F. & V TḦ & 1 & - \\
\hline \multirow[t]{3}{*}{ Vicia americana Muhl. ex Willd. } & White River N.F. & B adj. & 0.25 & - \\
\hline & & Pr adj. & 0.25 & - \\
\hline & Arapaho-Roosevelt N.F. & $\mathrm{V} \mathrm{TH}$ & 0.25 & - \\
\hline
\end{tabular}




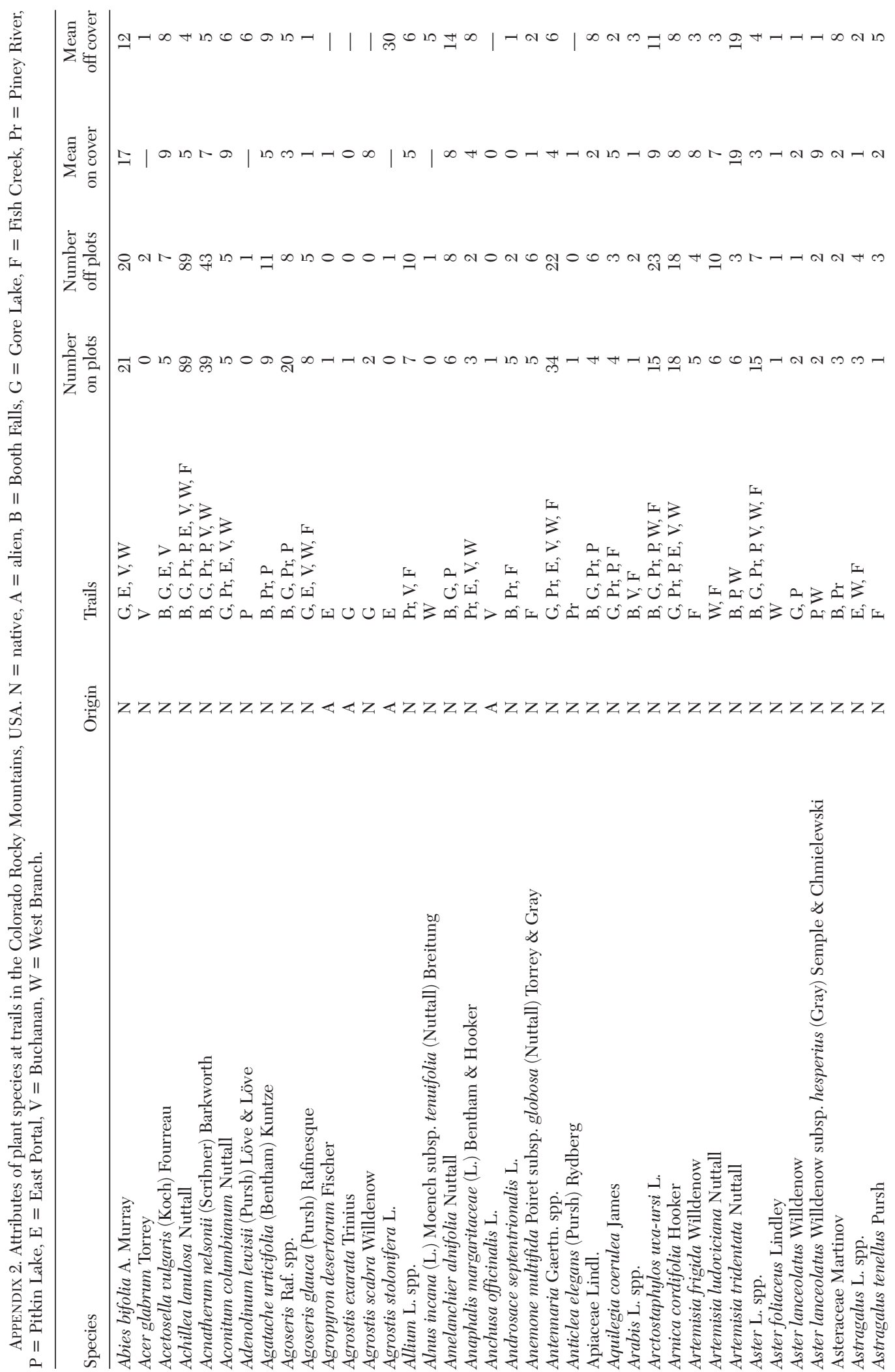




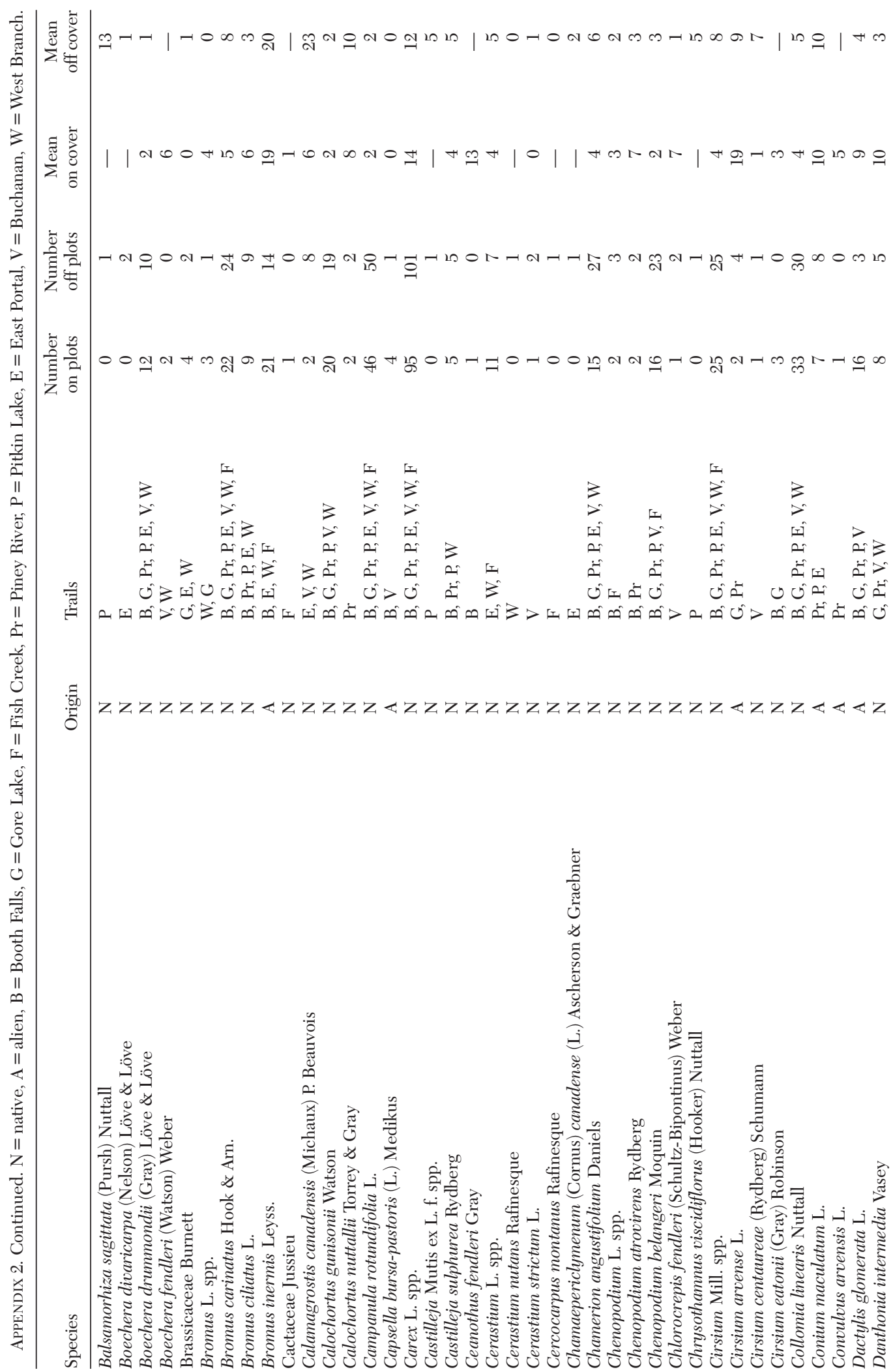




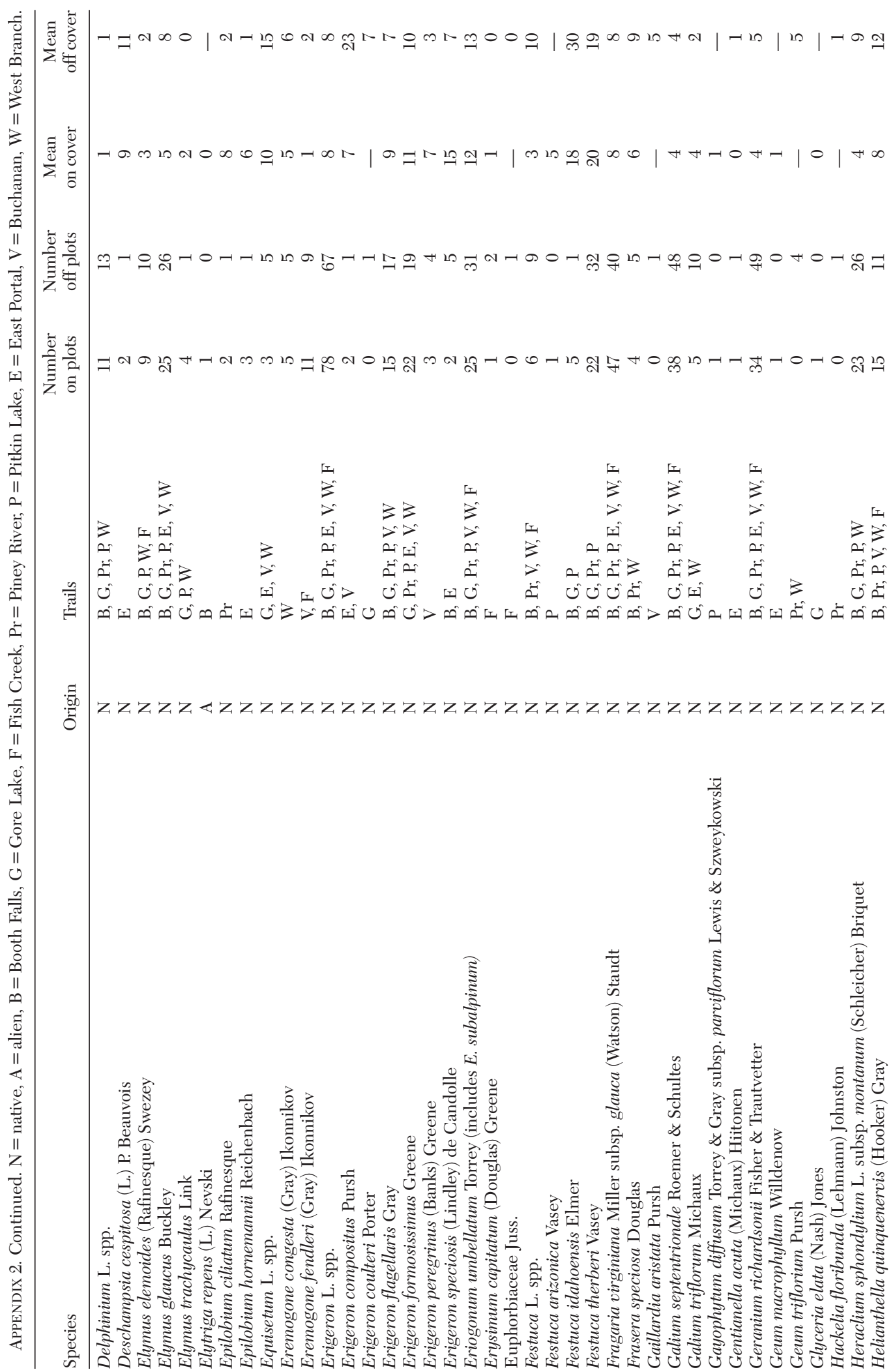




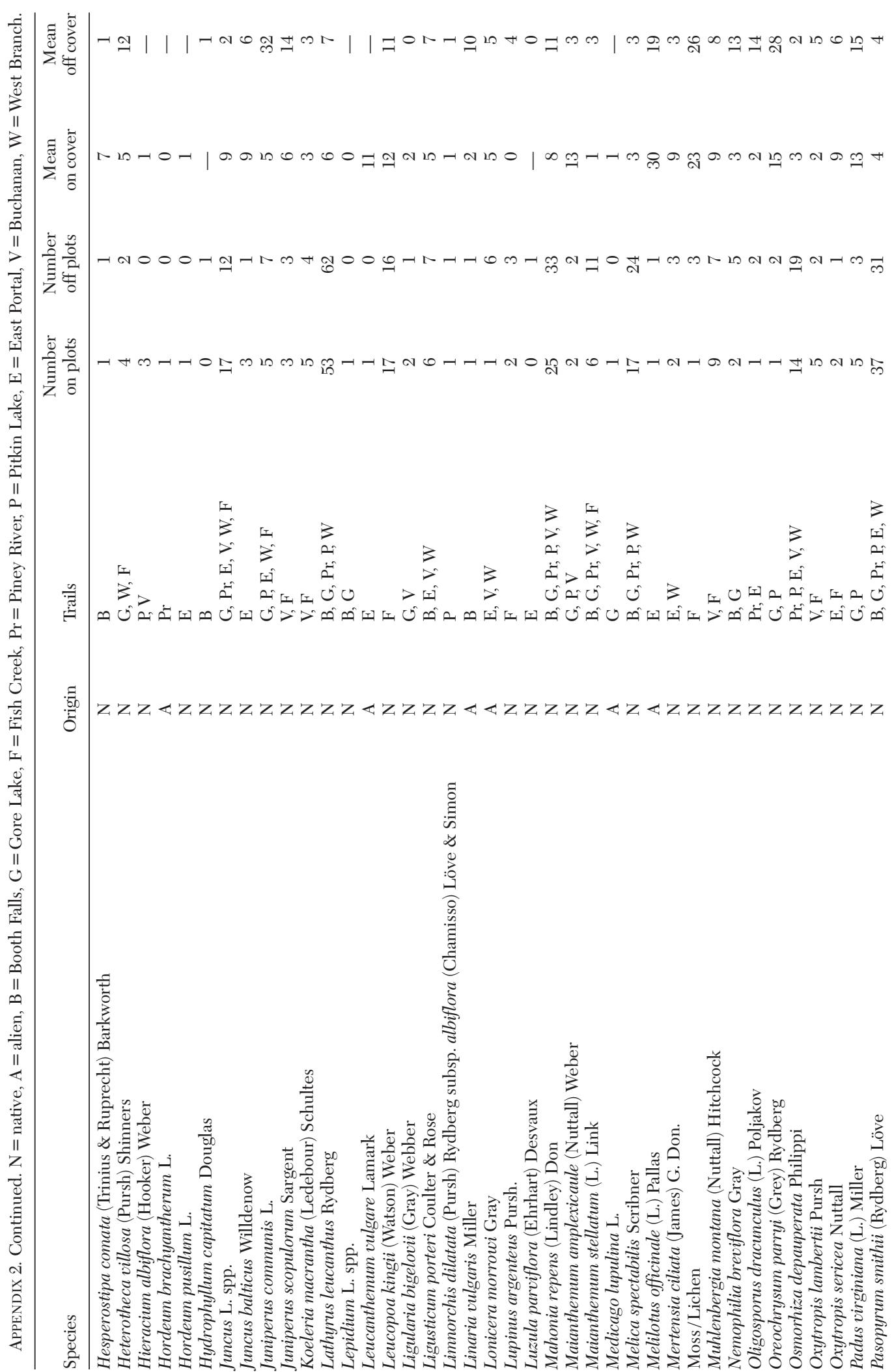




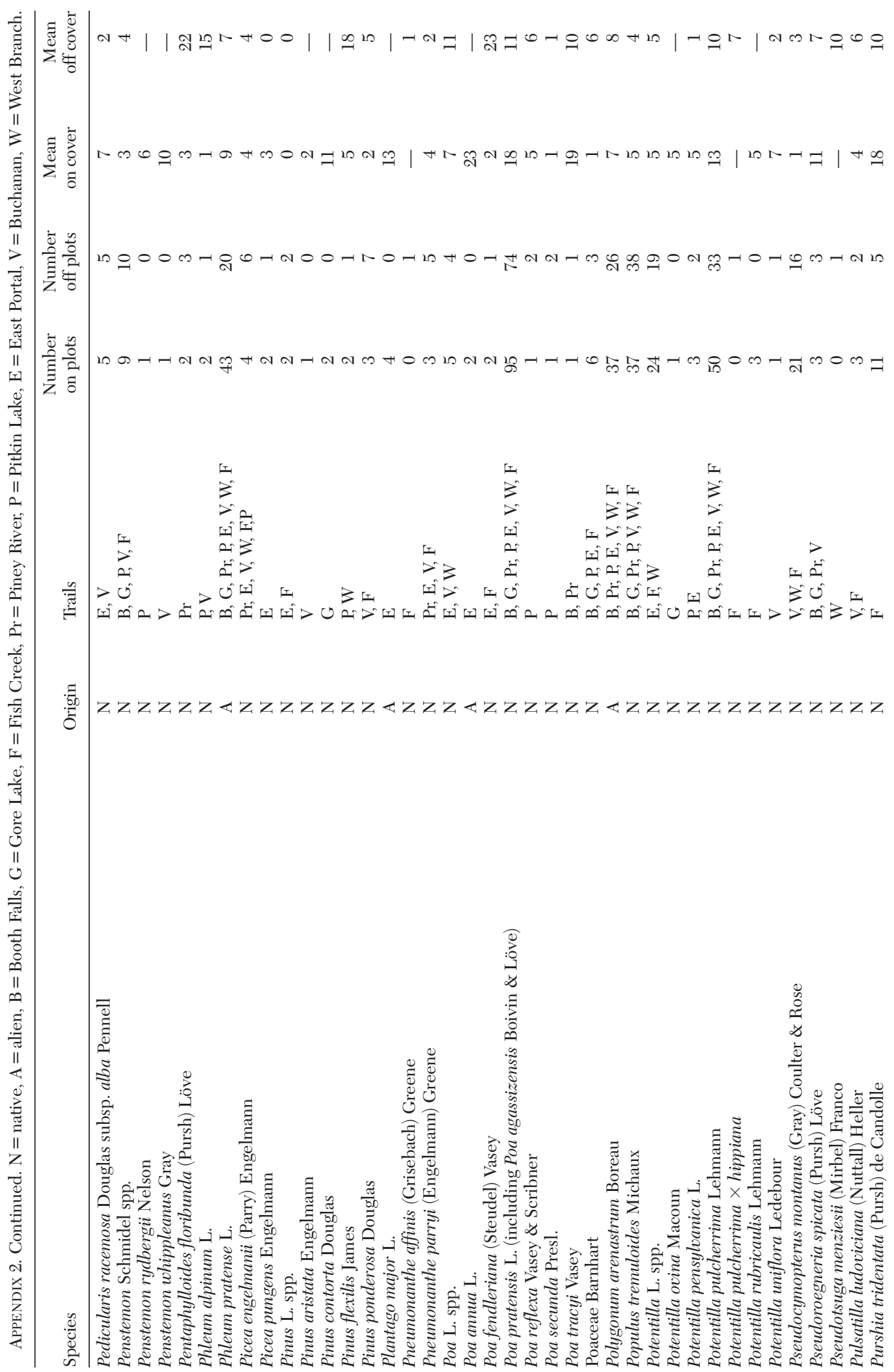




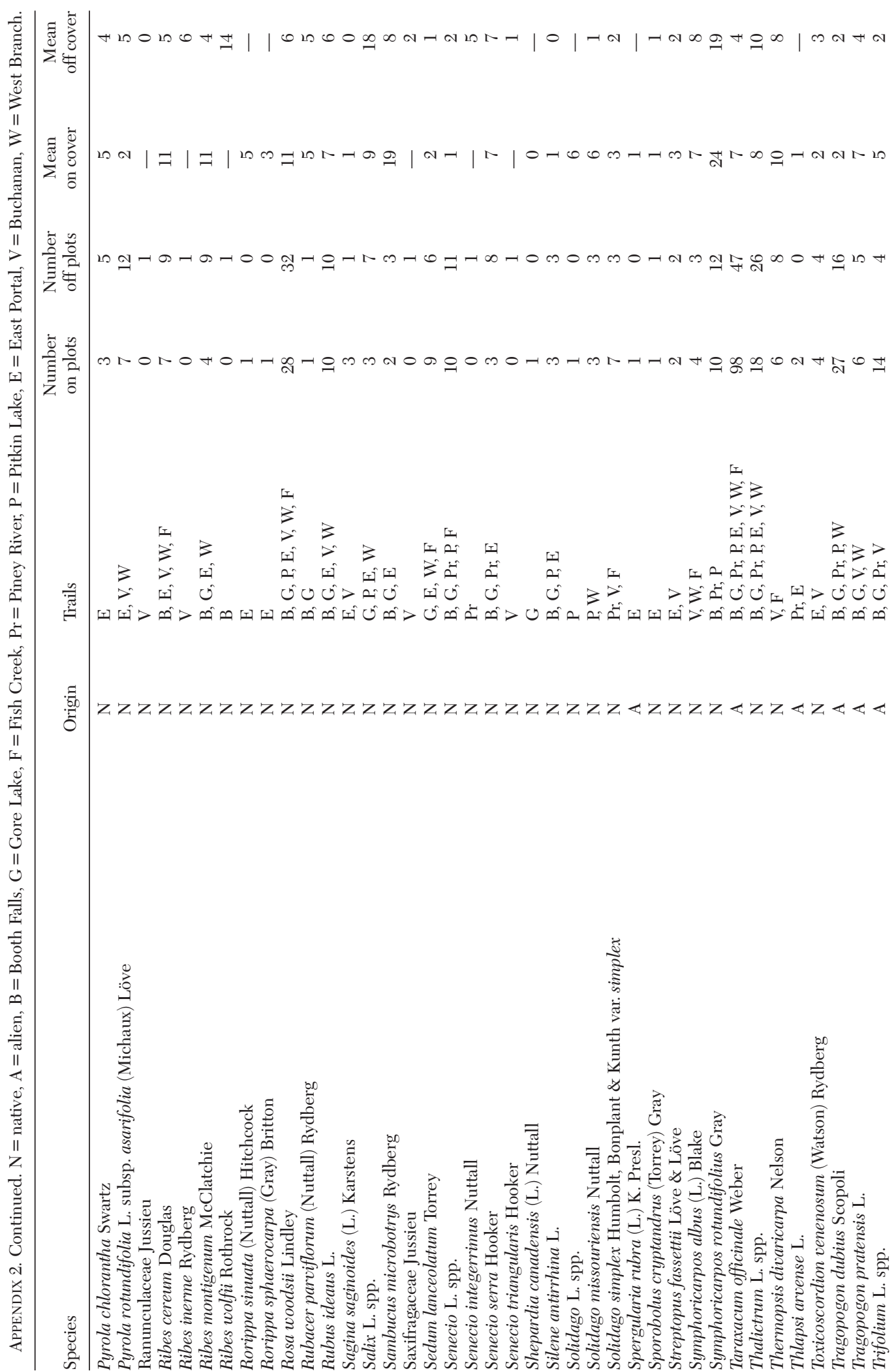




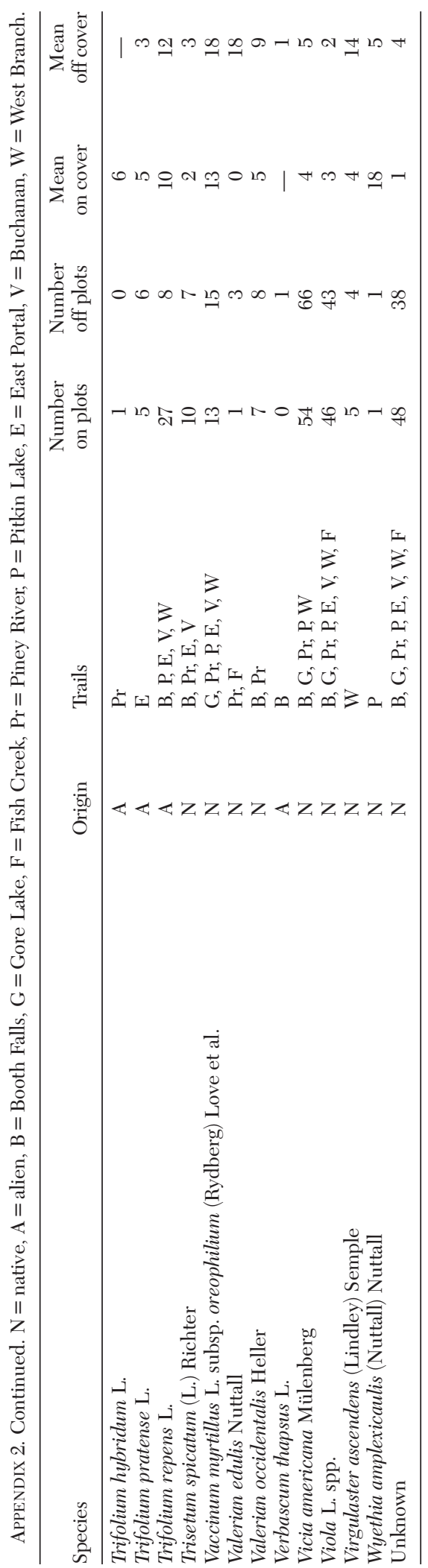

